\title{
THE BOWMAN LECTURE
}

\author{
GOTTFRIED O. H. NAUMANN \\ Erlangen. Germany
}

\section{PART I. HISTORICAL NOTES}

\section{SOME ASPECTS OF BRITISH, GERMAN AND EUROPEAN OPHTHALMOLOGY AROUND BOWMAN'S TIME}

Sir William Bowman gave Albrecht von Graefe a portrait photograph of himself at the age of 42 , signed 'To Dr Albrecht von Graefe from his sincere friend William Bowman, May 14, 1858' (Fig. 1). This picture, and another one showing Donders, were the only pictures on von Graefe's desk. At this time, Bowman was already a man of recognised accomplishments: his studies on the skeletal muscles prompted his election as Fellow of the Royal Society at the age of 25; his research on the anatomy of the kidney earned him the Royal Medal a year later (Table I). His observations (1847) on the ciliary muscle (independently of von Brücke) and even more so those on the anterior elastic lamina of the cornea' have made his name a household word in ophthalmologic practice to this day and reveal his capacity for precise detailed observation, quantification and convincing interpretation. The eponym of Bowman for the corneal lamina in fact made me choose this topic for the Bowman Lecture. $^{56.57}$ (Details of previous Lectures are given in the References. ${ }^{1-55}$ )

In 1851, Albrecht von Graefe visited the United Kingdom and Ireland, meeting Mackenzie in Glasgow and Wilde in Dublin. At Moorfields Hospital in London, Donders, Bowman and von Graefe discussed the exciting opportunities the newly developed ophthalmoscope provided. Bowman generously invited the 23-year-old von Graefe to stay for a month at his home Joldwynds in Dorking.

In a letter to his friend Waldau, Albrecht von Graefe gave the following impressions of this visit to London: 'I must praise the local scientists. It is a small circle of people working with iron industriousness and penetrating thoroughness ... As far as true lust and love of science is concerned, they certainly exceed the French and perhaps the Germans'... and, this I really can confirm from my own

Correspondence to: G. O. H. Naumann, MD, Professor and Chairman, Department of Ophthalmology. University of Erlangen-Nürnberg. Schwabachanlage 6, D-91054 Erlangen. Germany. Fax: 09131208207 experience, 'the English physicians excel in collegiality to foreigners and also - oh miracle - among themselves ${ }^{.58 .59}$ Later in the year, on 7 November. von Graefe wrote a letter to Hermann von Helmholtz asking for three of the latest version of his ophthalmoscope, not only for himself but also for Bowman in London and Desmarres in Paris, stressing 'particularly the first one [Bowman] is very interested in the scientific culture of his field and has extensive practical facilities at Moorfields Hospital; he would look forward to receiving your apparatus as soon as possible.$^{60}$ This is quite remarkable evidence of constructive international

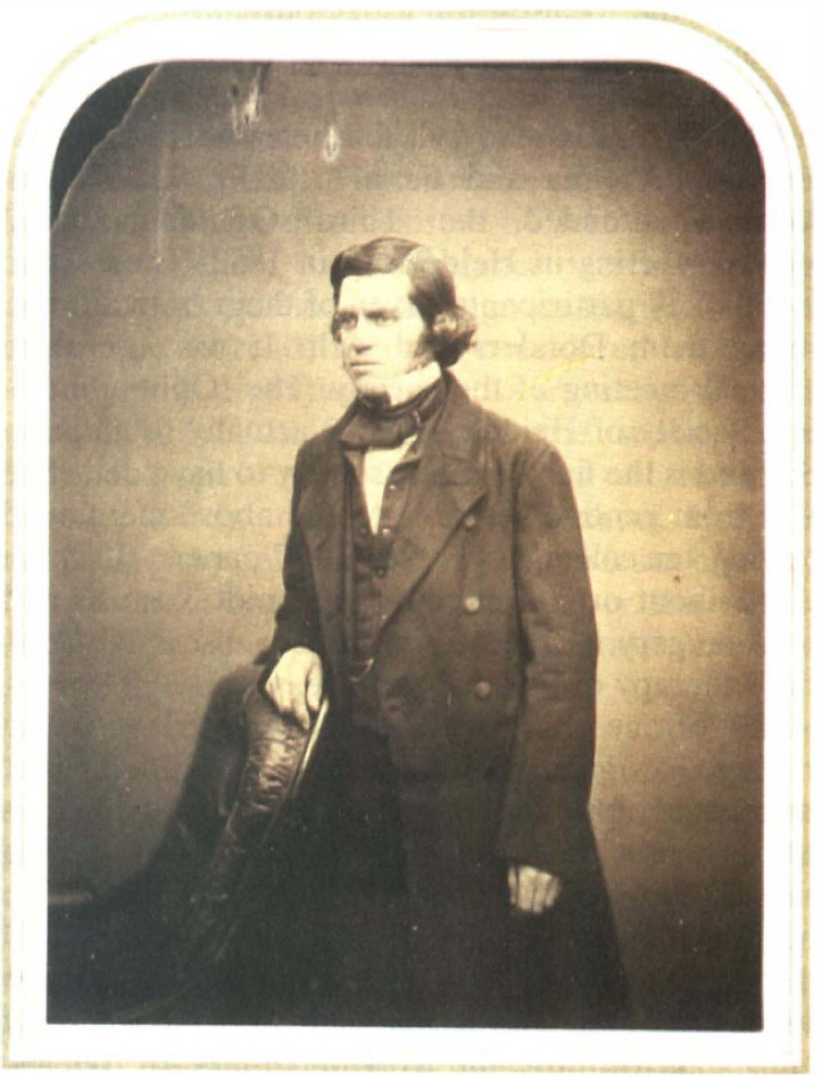

Fig. 1. Bowman's photograph signed 'To $\mathrm{Dr} A$. von Graefe from his sincere friend W. Bowman, May 14, 1858'. This and one of Donders were the only photographs on von Graefe's desk. (Courtesy of W. Jaeger, von Graefe Collection, Heidelberg.) 
Table I. Sir William Bowman: some aspects of his life

\begin{tabular}{ll}
\hline 1816 & $\begin{array}{l}\text { 20 July, born in Nantwich, Cheshire } \\
\text { Visited Hospitals in Holland, Germany, Vienna and }\end{array}$ \\
1838 & $\begin{array}{l}\text { Paris } \\
\text { Fellow of the Royal Society, for studies on skeletal } \\
\text { muscle histology }\end{array}$ \\
1842 & $\begin{array}{l}\text { Royal Medal, for research on kidney histology } \\
\text { 'Anterior elastic lamina' of the cornea; ciliary muscle } \\
\text { (with Brücke) }\end{array}$ \\
1847 & $\begin{array}{l}\text { Welcomed Donders and von Graefe at Moorfields } \\
\text { Hospital }\end{array}$ \\
1851 & $\begin{array}{l}\text { Attended Heidelberg Meeting (7 of 19 from abroad) } \\
\text { on 'The Conical Cornea . .' }\end{array}$ \\
$1857-1862 \begin{array}{l}\text { Supports von Graefe's iridectomy (but in a superior } \\
\text { location) }\end{array}$ \\
1880 & $\begin{array}{l}\text { Founder and First President of the Ophthalmological } \\
\text { Society of the United Kingdom }\end{array}$ \\
1884 & $\begin{array}{l}\text { Sir Jonathan Hutchinson delivers the Bowman } \\
\text { Lecture }\end{array}$ \\
1888 & $\begin{array}{l}\text { Bowman Testimonial Fund established } \\
\text { 29 March, died from pneumonia in London }\end{array}$ \\
\hline
\end{tabular}

co-operation in the middle of the last century.

Bowman apparently shared this sentiment of respect and appreciation. In his remarks from 1857 and 1863 accompanying the translation (by $\mathrm{Mr}$ Windsor of Manchester) of Albrecht von Graefe's paper on glaucoma and the results of iridectomy, Bowman defended the new approach in the treatment of glaucoma with great emphasis. $\mathrm{He}$ also modified the location for iridectomy: instead of the original temporal location he recommended a superior location. ${ }^{61-63}$

After he had already visited hospitals in Holland, Germany, Vienna and Paris in 1838, Sir William Bowman attended the Third Ophthalmological Society Meeting in Heidelberg in 1859. There were a total of 19 participants, seven of them from abroad, among them Donders and Arlt. It was the third informal meeting of the society. The 'Ophthalmological Society of Heidelberg' was actually founded in 1863 and is the first specialty society to have detached itself from general surgery. At the above-mentioned meeting, ten colleagues presented 17 papers. Bowman talked about orbital tumours, ethmoid exostosis and ptosis surgery. Albrecht von Graefe discussed Bowman's therapy of lacrimal sac diseases. ${ }^{64}$

One of the many rewards associated with the privilege of giving the Bowman Lecture is the unexpected but great pleasure of studying his publications. They not only reveal the towering scientist the world knows, ${ }^{56,64-66}$ but also show an amazing human being with a great heart and soul who, in language still vivid, seems to speak to us to this day. He was truly a 'magnanimus'. He went out of his way to praise the work of others. In 'On the "Immortal Helmholtz"' - a particularly touching headline in a paper presented at the Thirtieth Meeting of the British Medical Association, 5-8 August 1862 (published only 8 weeks later in October 1863) he said: 'We are fallen on a time that will be for ever memorable in the history of ophthalmic science, the epoch of the invention of the ophthalmoscope... So long as there are human eyes to suffer from disease or are cultivators of the fine art of healing, so long will the ophthalmoscope be in universal use and the name of Hermann von Helmholtz held in honour among mankind'. ${ }^{63}$ And in giving a eulogy on the 'Splendid Researches of Albrecht von Graefe on Glaucoma and Iridectomy' in 1881 , at the opening of the International Medical Congress in London - 11 years after von Graefe's death! - he called him 'that bright spirit, whose premature death we have not ceased to mourn for ourselves and for science. ${ }^{67}$

In 1869 Bowman met von Graefe for the last time in Naples, Italy, a meeting recorded in a photograph of them both. von Graefe, though 12 years younger, is obviously suffering from the advanced stages of the tuberculosis that killed him in the following year (Fig. 2).

In 1880, Sir William Bowman was instrumental in founding the Ophthalmological Society of the United Kingdom and was its first President for three years. In $1881,{ }^{68,69}$ Bowman had to write an obituary for his friend Franz Cornelius Donders: 'He had the fortune to have contributed to the advancement of his specialty and lived long enough to see the fruit of

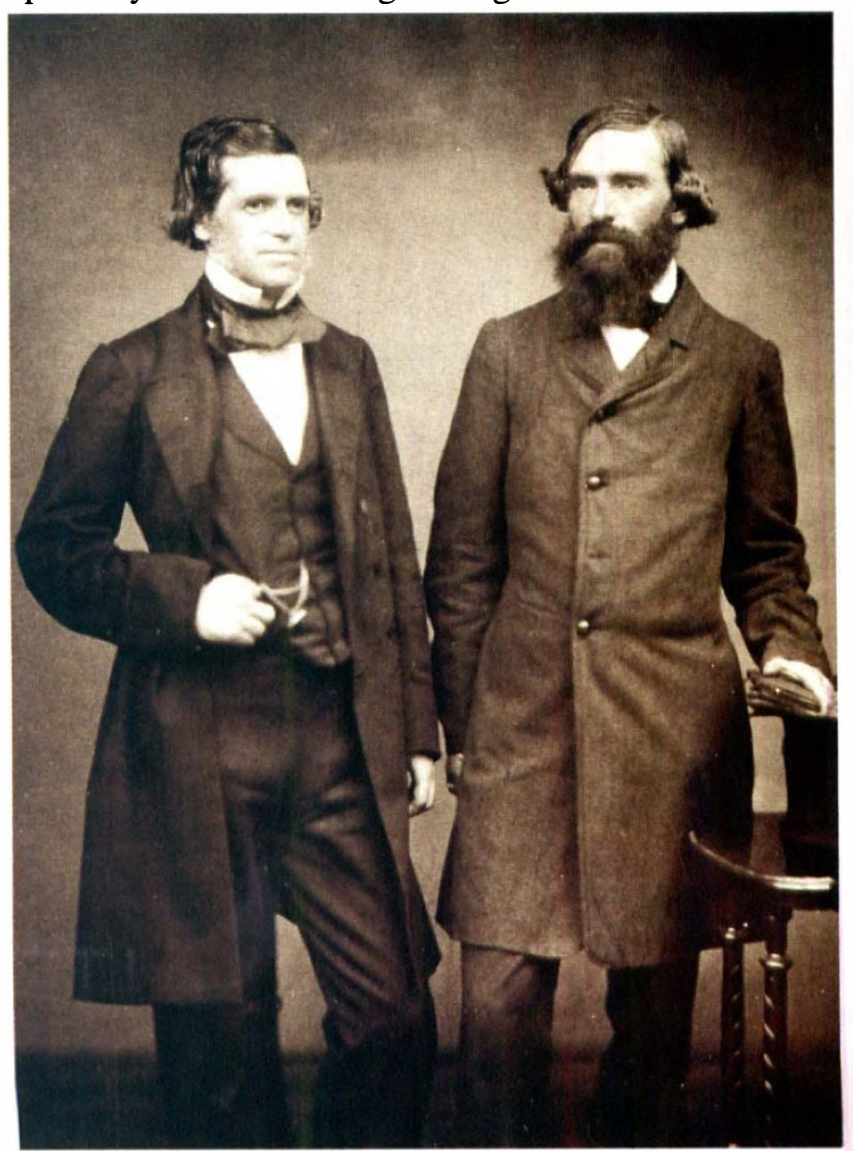

Fig. 2. Sir William Bowman and Albrecht von Graefe in 1869 at their last meeting in Naples. von Graefe, who was 12 years Bowman's junior, died from tuberculosis in 1870. (Courtesy of W. Jaeger, von Graefe Collection, Heidelberg.) 
his work universally recognised'. Hirschberg is quoted by $M$. Amsler ${ }^{32}$ (in the Thirty-second Bowman Lecture, 1948) as saying that this would have been a very fitting obituary to Sir William Bowman himself, who died on 29 March 1892.

At the Twenty-second Annual Meeting of the Ophthalmological Society in Heidelberg, Wilhelm von Zehender read Bowman's obituary during its first session on 8 August 1892: 'Bowman once attended our meeting during the early years of our society. He was, as you all know, primus omnium among English ophthalmologists; nobody would have dared to challenge him for this position. Everyone who knew him will always remember his fine, noble, kind and pious character. Our Society can be proud to count among its members, in addition to Albrecht von Graefe and Donders, also William Bowman'.64

The Ophthalmological Society of the United Kingdom inaugurated the Bowman Testimonial Fund in July 1888. The list of contributors from all over the world in September 1892 reveals the obvious admiration and affection the leaders of the international medical scientific community had for Bowman. ${ }^{56}$ Among the 442 international contributors, 33 were from Germany and represented the elite of medical science in my country; I am happy to note that three were from Erlangen (Michel, Rosenthal and Sattler). Four of these German contributors were also Fellows of the Royal Society (Du Bois-Reymond and von Helmholtz from Berlin, Ludwig from Leipzig and Pflüger from Bonn).

\section{ESTABLISHMENT OF THE BOWMAN LECTURE}

At meetings of the Council of the Ophthalmological Society of the United Kingdom on 18 September and 11 October 1883, Dr Stephen Mackenzie moved and Dr Spencer Watson seconded the following resolution, which was unanimously agreed on, to establish the Bowman Lecture: ${ }^{70}$ 'That in recognition of $\mathrm{Mr}$ Bowman's distinguished scientific position in ophthalmology and other branches in medicine and in commemoration of his valuable services to the Ophthalmological Society of which he was the first president, the Council shall each year or periodically nominate some person to deliver a lecture before the Society to be called "The Bowman Lecture" which shall consist of a critical résumé of recent advances in ophthalmology or in such subjects as the Council shall elect or in any original investigation and shall be delivered at a special Meeting of the Society held for the purpose at which no other business shall be transacted.' The Bowman Lecture served as an example to establish other lectureships. ${ }^{71,72}$

Donders was invited to give the first lecture but declined (M. Hallendorff, personal communication).
In $1884 \mathrm{Sir}$ Jonathan Hutchinson ${ }^{1}$ initiated The Bowman Lecture with a paper on 'Certain Diseases of the Eye to Gout'. Four of the first 19 Bowman Lecturers were from Germany. In the third lecture, in 1886, Wilhelm von Zehender of Rostock, the cofounder (with Albrecht von Graefe) of the journal Klinische Monatsblätter für Augenheilkunde, which is one of the first ophthalmologic journals, talked about 'Parasitic Diseases of the Eye'. In the eighth Lecture, held in 1892, Theodor Leber of Heidelberg spoke on the 'Present Position of our Knowledge of Inflammation'. ${ }^{8}$ In 1907, Hubert Sattler of Leipzig in the sixteenth Lecture discussed 'The Pathology and Treatment of Myopia'. ${ }^{16}$ I particularly enjoyed his introductory comments - not only because he was originally from Leipzig (where I went to medical school) but also because he served in Erlangen as the second Chairman of the Department of Ophthalmology and is thus one of my predecessors. His vivid account of a visit to Bowman recalls 'the privilege of seeing Sir William Bowman at work on Tuesday and Friday in Moorfields Ophthalmic Hospital' and admires him as a 'scientific practitioner' and 'surgeon of unequalled skills', also stressing the 'winning kindness he bestowed on me, a young man without merit at that time'.

In 1914, W. Uthoff of Breslau in the nineteenth Bowman Lecture discussed 'Ophthalmic Experiences and Considerations on the Surgery of Brain Tumours and Tower Skull'. He characterised Bowman as follows: 'for him there existed no territorial boundaries in science, a circumstance which was ever gratefully recognised in foreign countries. Both at home and abroad, he was considered a man of learning and a gentleman in the truest sense of the word'. And Uthoff expressed the wish that in Bowman's spirit 'many individuals as well as nations be ever ready to acknowledge without envy the merits of others and be ever willing to learn one from the other'. ${ }^{19}$ Only a few months after this sincere declaration, Europe drowned in catastrophies for several decades.

The sentiments voiced by these four former Bowman Lecturers from Germany are shared by my colleagues and myself, while we all work together with our fellow ophthalmologists for closer cooperation in ophthalmology within the European Union. Since 1986, the European University Professors of Ophthalmology (EUPO) and, since 1992, the European Board of Ophthalmology (EBO) have tried to be constructive elements in advancing this spirit. Their goal is to associate and include European ophthalmologists still outside the European Union for the sake of the patients. It is to be hoped that European ophthalmologists will then be able to contribute even better to international ophthalmology. 


\section{PART II}

\section{CORNEAL TRANSPLANTATION IN ANTERIOR SEGMENT DISEASES}

The special immunological privileges of the cornea allowed Zirm, ${ }^{74}$ as early as 1905 , and many others in ophthalmology following him, to be pioneers in human transplantation - so it is an old-established procedure and there are numerous experts. ${ }^{75-98} \mathrm{An}$ encyclopaedic approach is neither intended nor possible here, but I shall attempt to touch on the following four aspects of the subject in an eclectic fashion:

1. Spectrum of indications for corneal transplantation: Why are optical indications only part of the wide spectrum of different reasons for performing a corneal graft? (Figs. 3, 4)

2. Some aspects of surgical technique: How does Bowman's lamina represent a 'critical structure' in corneal surgery? Are there advantages to a nonmechanical trephination of the cornea in penetrating keratoplasty, e.g. with the $193 \mathrm{~nm}$ excimer laser?

3. Corneal graft-versus-host effects: What can we learn from looking more closely at the often disregarded effects of the corneal transplant on the recipient's cornea?

4. New approaches to some old problems in corneal transplantation.

\section{SPECTRUM OF INDICATIONS FOR CORNEAL TRANSPLANTATION}

Obviously corneal transplantation is usually done for optical indications and the graft is placed in the centre of the cornea. Tectonic corneal transplants at an eccentric location are less often discussed although they are essential for preservation of the globe.

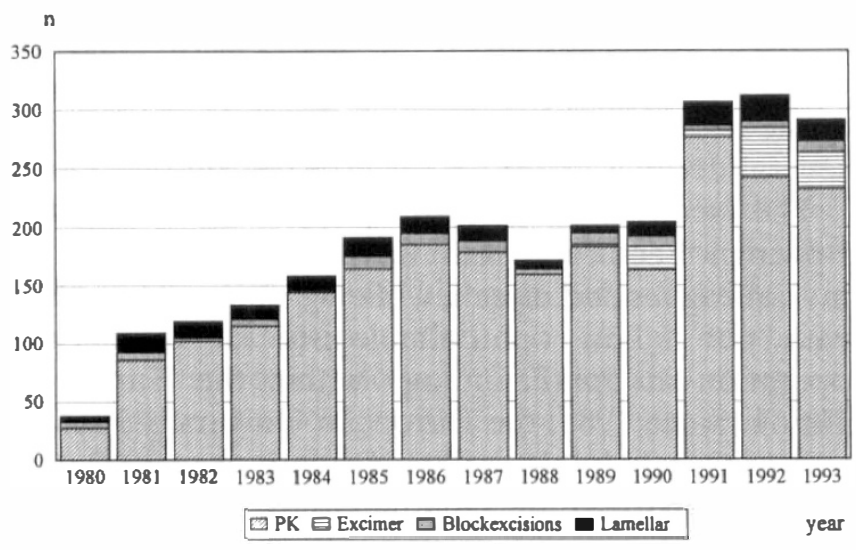

Fig. 3. Corneal transplantations performed at the Department of Ophthalmology, University Erlangen-Nürnberg in Erlangen 1980-1993. PK, conventional penetrating keratoplasties. 'Excimer' indicates non-mechanical trephination in $P K$ with the $193 \mathrm{~nm}$ excimer laser along a metal mask; this was first performed on two patients in June 1989. Block excision includes eccentric tectonic corneoscleral grafting.

\section{Tectonic Eccentric Corneoscleral Transplantation}

Corneoscleral Graft after Block Excision for Anterior Uveal Tumours

Full-thickness grafts are necessary to close iatrogenic defects in the eye wall following block excision. ${ }^{100-104}$ If anterior uveal tumours involve the angle of the anterior chamber, it is impossible to detect the degree of scleral invasion clinically, especially if the tumour cells are not pigmented. But we must be certain that the tumour is indeed strictly localised and that there is no evidence of tumour cell shedding into the aqueous. An effort must be made to assess the 'biocytology' of cells on the surfaces of the lens, iris and angle structures. This is worthwhile and it is also possible to study individual cells at the slit lamp with $\times 40$ magnification in order to distinguish malignant from benign melanocytic cells.

'Biocytology' should be attempted in every examination of tumour of the anterior uvea. The sometimes loosely used term 'pigment dispersion' actually covers several entirely different phenomena. We can recognise with relative ease, particularly on light-coloured irises, the following morphological elements. (Unfortunately due to physiological pulsation and micronystagmus they are rather difficult to photograph!) Mature benign melanocytes are an everyday sight on the central anterior lens surface as remnants of the pupillary membrane and at the margins of naevi of the iris. These obviously benign melanocytes show bulging nuclei and a dendritic pattern. Malignant melanocytes look quite different, are more fusiform and reminiscent of those growing

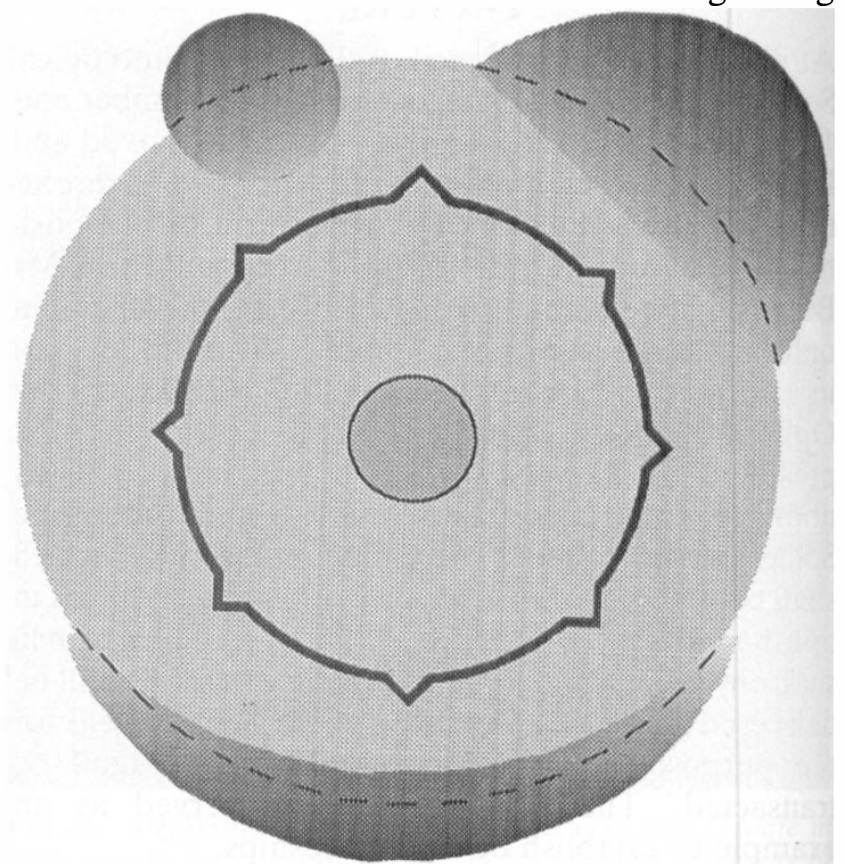

Fig. 4. Spectrum of corneal transplantation: central optical indication, and various tectonic corneal grafts at the limbus. 
in tissue culture. Melanin granules from the iris pigment epithelium are also familiar. They float freely in the anterior chamber or are phagocytosed in corneal or trabecular endothelial cells as part of juvenile pigmentary glaucoma, pseudoexfoliation syndrome, diabetic pigment epithelial iridopathy, or following contusion or local long-term mydriatic therapy. Melanophages containing mainly uveal melanin granules are evident in areas of iris stroma necrosis following pupillary block in angle closure glaucoma, zoster ophthalmicus or herpetic keratouveitis. Macrophages containing haemosiderin or lipofuscin are more difficult to make out as they show less contrast to the surrounding iris tissue. ${ }^{105}$

Our technique of block excision for uveal tumours ${ }^{100-104}$ and epithelial ingrowth has been modified only in minor details: Prophylactic retinopexy is not indicated if the area of resection does not reach $4-5 \mathrm{~mm}$ behind the limbus. If the block excision reaches more posteriorly, cryocoagulation or laser coagulation of the peripheral retina is necessary to prevent retinal detachment after excision. As the ciliary muscle is completely removed in the sector of resection, separation of the anterior uvea from the sclera in the sense of a cyclodialysis does not occur. Intraoperatively temporary controlled arterial hypotension ${ }^{106}$ reduces the haemorrhage from the wound edges of the ciliary body - as does bipolar cautery of the ciliary artery using minute forceps. The composite sclerocorneal graft is as reliable as the pure corneal transplant formerly used. It is fixed with direct $8-0$ or $10-0$ interrupted sutures at the scleral wound edges, with running 10-0 nylon at the corneal cuts. ${ }^{103,104}$

Results. Wound leaks have never been observed in our total series of more than 140 block excisions followed by an eccentric tectonic corneoscleral graft. Immune reactions of the eccentric grafts occur in almost all eyes after varying intervals with a few notable exceptions (Figs. 5, 6). Mortality after 90 block excisions for tumours compares favourably with series of enucleations; the functional results are acceptable.

\section{Corneoscleral Graft after Block Excision for Diffuse and Cystic Epithelial Ingrowth}

This approach is used in analogy to excision for anterior uveal tumours to prevent recurrences. ${ }^{103,107-}$ ${ }_{109}$ With the exception of small epithelial implantation cysts within the iris stroma, the delicate lining of the cyst, which is sometimes made up of only one or two layers of epithelial cells, is always fused to the anterior ciliary body face and is so friable that it cannot be separated - even by the most skilful microsurgical manoeuvre - from the adjacent tissues of the anterior segment of the eye. Therefore the neighbouring cornea and sclera are used as a 'shell' for complete block removal of the invading epithelium. With the exception of a grossly visible external fistula, the sometimes labyrinthine course of the invading epithelial strands cannot be detected by clinical means as is evident from histopathological examination. In our view, the only approach to removing all non-pigmented transparent ducts between surface epithelium and intraocular cyst is to remove the adjacent cornea and sclera.

At present the resulting defect in the eye wall can be closed only by a full-thickness corneoscleral graft (Fig. 6). We have learned to decrease the size of the defect in the eyewall by shrinking the diameter of the cyst by a combination of draining it externally (through a transcorneal stab incision involving tissue later removed) and compressing it with Healon injected into the anterior chamber.

Results. In our experience with more than 60 block excisions for cystic and diffuse epithelial ingrowth, no recurrence was seen and the functional results are acceptable. $^{108} \mathrm{We}$ therefore suggest that our approach currently seems to be the therapy of choice.

Corneoscleral Graft after Block Excision for Congenital and Infantile Cysts of Iris and Ciliary Body

Congenital 'iris cysts' are practically always attached not only to the retrocorneal surface but - very much like cystic epithelial ingrowth - to the anterior ciliary body face. ${ }^{109,110}$ Some can be traced to amniocentesis. ${ }^{111} \mathrm{We}$ are therefore convinced that these processes require the same approach as cystic epithelial ingrowth, even though at first sight this may be judged radical!

Results. In our small series of 7 patients treated by block excision and full-thickness corneal graft, we achieved a cure without recurrence. ${ }^{110,111}$ Less radical measures may be followed by a $25 \%$ enucleation rate, in addition to other evidence of incomplete removal. ${ }^{112,113}$

\section{Other Indications for Eccentric Tectonic Corneal Transplantation}

Simultaneous 'Direct Cyclopexy' and Patch Graft for Persisting Ocular Hypotony Syndrome. Indications for patch grafts are a combination of external fistula and extensive cyclodialysis after trauma: We treated in this way 3 eyes from a series of 40 consecutive patients with traumatic cyclodialysis. A full-thickness corneal graft is fixed in a deep lamellar scleral bed. Our technique of direct cyclopexy ${ }^{114}$ is a modification of the approach used by McCannel and Mackensen. The critical reapposition of the severed ciliary muscle to the scleral spur can be performed under direct microscopic control through the remaining deep scleral layers after a thick lamellar limbusbased flap has been made. 


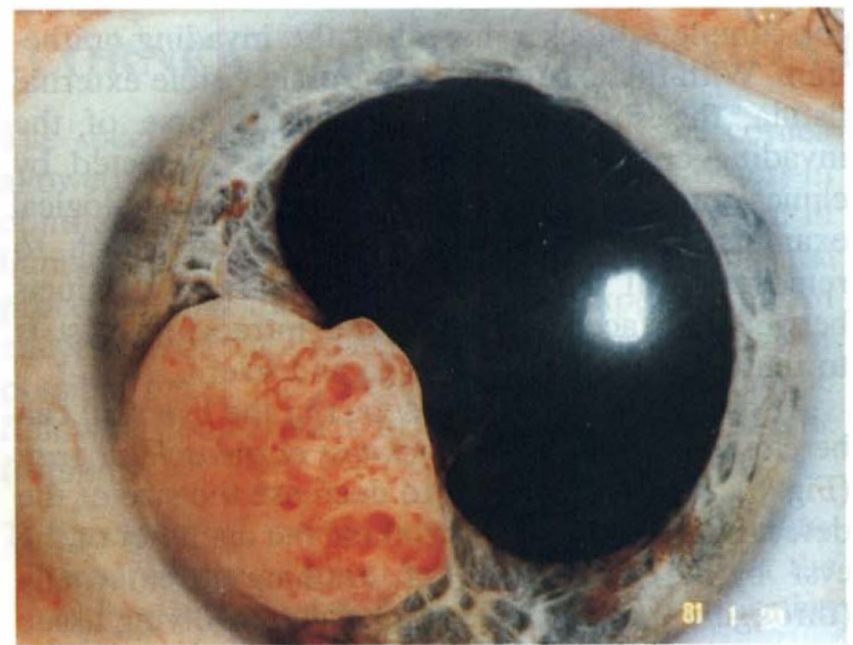

(a)

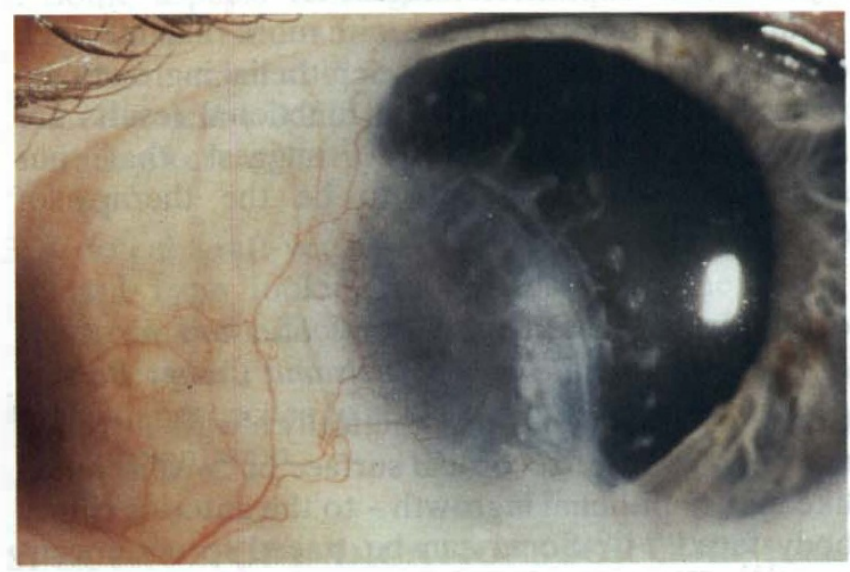

(c)

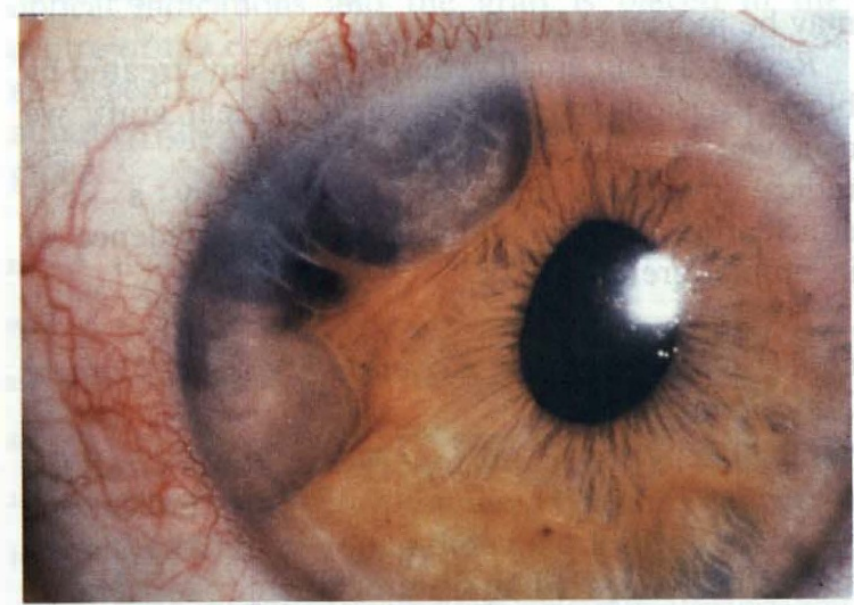

(a)

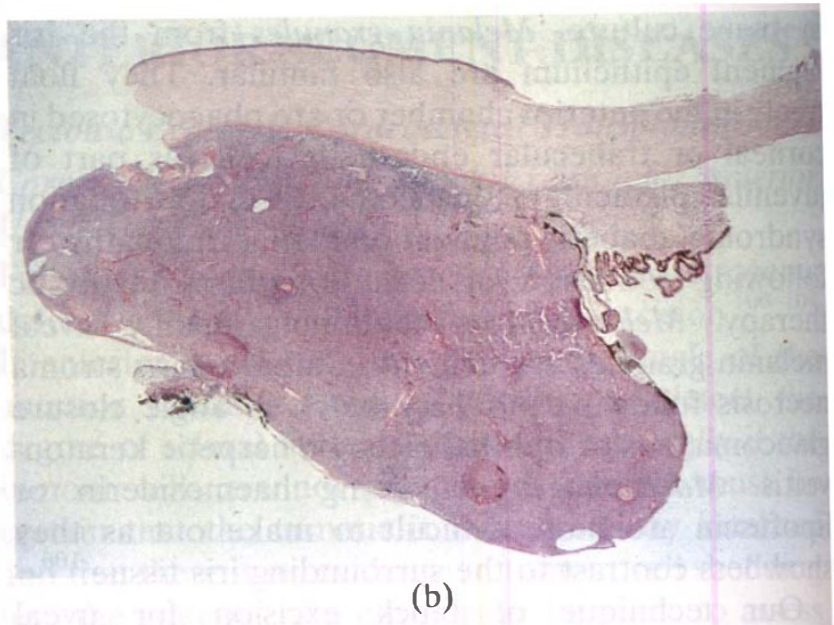

(b)

Fig. 5. Tectonic corneoscleral graft after block excision for malignant melanoma of the iris and ciliary body. (a) Preoperatively, after recurrent anterior chamber haemorrhage in a 47-year-old man. (b) Histology: mixed malignant cell melanoma (PAS-haematoxylin). (c) Thirteen years after block excision and tectonic corneoscleral graft of $7.5 \mathrm{~mm}$ diameter reaching $3.5 \mathrm{~mm}$ behind the limbus: the graft is vascularised and opaque.

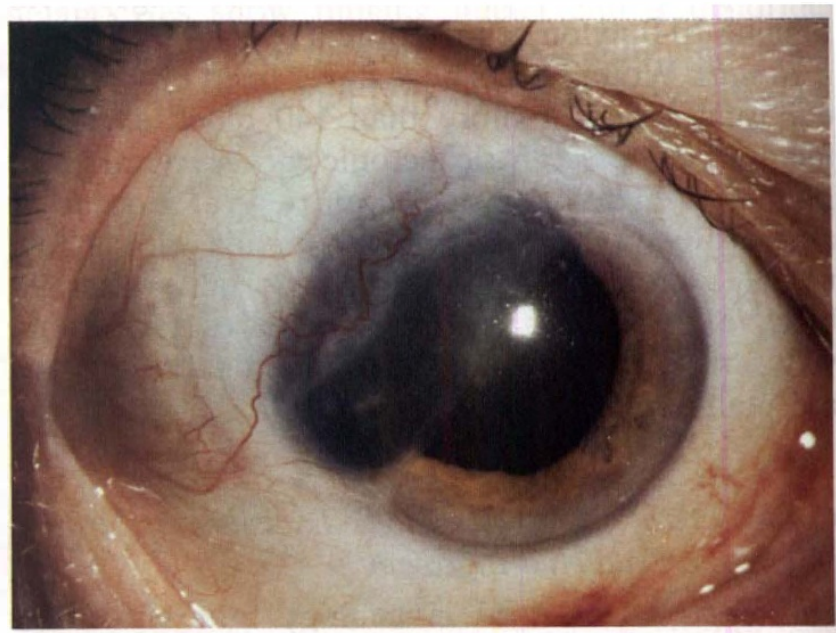

(b)

Fig. 6. Tectonic corneal graft after block excision for a rapidly growing cystic epithelial ingrowth 2 years after puncture trauma in a 45-year-old man. (a) Pre-operatively. (b) Nine years after $10 \mathrm{~mm}$ block excision and tectonic corneoscleral graft: as an exception to the rule, the corneal transplant remains clear.

Results. In our total series of 50 eyes, persisting peripheral anterior synechiae did not develop; there was a transitory post-operative pressure rise for a few days, but no persisting secondary glaucoma occurred. $^{115}$
Patch Graft in Peripheral Corneal Defects. Peripheral marginal degeneration, Fuchs-Terrien's keratolysis or peripheral corneal perforations, and both infectious and other ulcers following trauma, ${ }^{116-118}$ are indications for using this technique. The eccentric 
full-thickness crescent graft is fixed end-to-end to the central corneal wound edge and placed in a very deep lamellar scleral bed. Preservation of the scleral spur appears to be crucial. ${ }^{117}$ Removal of the scleral spur might result in cyclodialysis. The corneal graft is then fixed in the lamellar bed overlying the scleral spur using interrupted sutures. The suturing is facilitated by undermining the posterior scleral wound edges by means of lamellar dissection.

\section{Neglected, Perhaps New Optical Indications for Corneal Transplantation}

The usual optical indications for corneal transplantation are known to all ophthalmologists and do not need to be mentioned here. Technical details are discussed in the section on Aspects of Surgical Technique. Here I will focus on new entities.

\section{Endothelial Keratopathy in Pseudoexfoliation Syn- drome ('PEX Keratopathy')}

In 1917, before slit lamps were in general use, Lindberg ${ }^{119}$ described pseudoexfoliation syndrome as characterised 'by peculiar deposits on the anterior lens surface, resembling the changes seen in glass blower's cataract'. Its clinical significance as a vicious type of glaucoma was stressed as early as 1925 by Vogt, who called it 'glaucoma capsulare'. ${ }^{120}$ The exact role of the pseudoexfoliation material among other types of chronic to subacute glaucoma is still controversial. ${ }^{121,122}$ Recently, interest in pseudoexfoliation syndrome has been renewed by observations of a markedly increased risk of vitreous loss in extracapsular cataract extraction explained by the diminished mydriasis or mainly by the instability of the zonular apparatus, clinically often recognisable as phacodonesis. ${ }^{123}$ The reasons for zonular instability have been demonstrated electron-microscopically by striking alterations at three crucial regions: (1) at the anchoring of the zonular fibres in the non-pigmented ciliary epithelium, (2) the enzymatic erosion at the tips of the ciliary processes and (3) enzymatic erosion at the insertion in the anterior lens capsule. ${ }^{124}$

As was first shown in our laboratory ${ }^{125}$ - and quickly confirmed by others ${ }^{126}$ - pseudoexfoliation syndrome is not exclusively an intraocular process, but also involves extraocular muscles, the walls of vortex veins, meninges of the optic nerve, and is, in fact, a systemic alteration involving heart, lung, liver, kidney, skin, meninges and gallbladder.

Corneal Endothelial Decompensation. In view of the systemic findings, it is no longer surprising that our clinical observation of corneal endothelial decompensation in pseudoexfoliation syndrome - even with moderate rises in the intraocular pressure, e.g. with diagnostic mydriasis ${ }^{127}$ - is indeed caused by direct involvement of the corneal endothelial cells (Fig. 7). This has quantitative and qualitative aspects: (1) The number of corneal endothelial cells is significantly decreased, even without increased intraocular pressure, and these cells show alterations. ${ }^{128,129}$ (2) There is clear evidence of direct production of pseudoexfoliative material by corneal endothelial cells themselves ${ }^{130,131}$ (Fig. 8).

The capacity of the corneal endothelial layer to compensate for corneal hydration is apparently enormous even if the number of cells decreases and individual endothelial cells are sick (Fig. 8). Clearing of the cornea by reduction of a moderate intraocular pressure rise from approximately $30 \mathrm{mmHg}$ to about $20 \mathrm{mmHg}$ is often striking. However, the limits of compensation are reached if the affected endothelial cells are additionally damaged by intraoperative traumatic manipulation. The surgeon can therefore be unpleasantly surprised by a cloudy cornea in eyes with pseudoexfoliation syndrome on the first postoperative day even following gentle glaucoma or cataract surgery. ${ }^{127,130}$ In the advanced stages of pseudoexfoliation syndrome, the corneal endothelial decompensation may become irreversible and may thus present an indication for keratoplasty, above all in very old patients. We performed penetrating keratoplasty in 7 such patients. Three of these showed clear evidence of local production of pseudoexfoliative material in the remaining endothelial cells. ${ }^{131}$

Differential Diagnosis: Cornea Guttata. Pseudoexfoliation syndrome keratopathy can be associated with cornea guttata (as an unspecific alteration, e.g. after stromal keratitis, iritis or contusion). The differential diagnosis has to deal with idiopathic 'cornea guttata' and Fuchs' endothelial-epithelial corneal dystrophy. ${ }^{132-136}$ There are obvious similarities and differences: Both are not confined to the cornea. Aside from the corneal endothelial decompensation, both develop a nuclear cataract sooner or later. But in classical Fuchs' corneal dystrophy, the iris stroma and epithelium are not affected, there is no phacodonesis, the incidence of open-angle glaucoma is not significantly increased and pseudo-uveitis is absent (Table II).

Melanin Dispersion. Trabecular pigmentation with corneal endothelial decompensation should alert the ophthalmologist to the possibility of $(P E X)$ keratopathy if other reasons for pigment dispersion, such as poorly controlled diabetes mellitus, can be ruled out. Perhaps PEX keratopathy covers the entity 'atypical Fuchs' as used in the past. As life-expectancy increases, I suspect that we are going to see the diffuse corneal endothelial decompensation caused by PEX keratopathy more often. We should then pay special attention to the surgically relevant phacodonesis and open-angle glaucoma. Clinically, this endothelial decompensation can be distinguished from the corneal oedema in cornea guttata and 


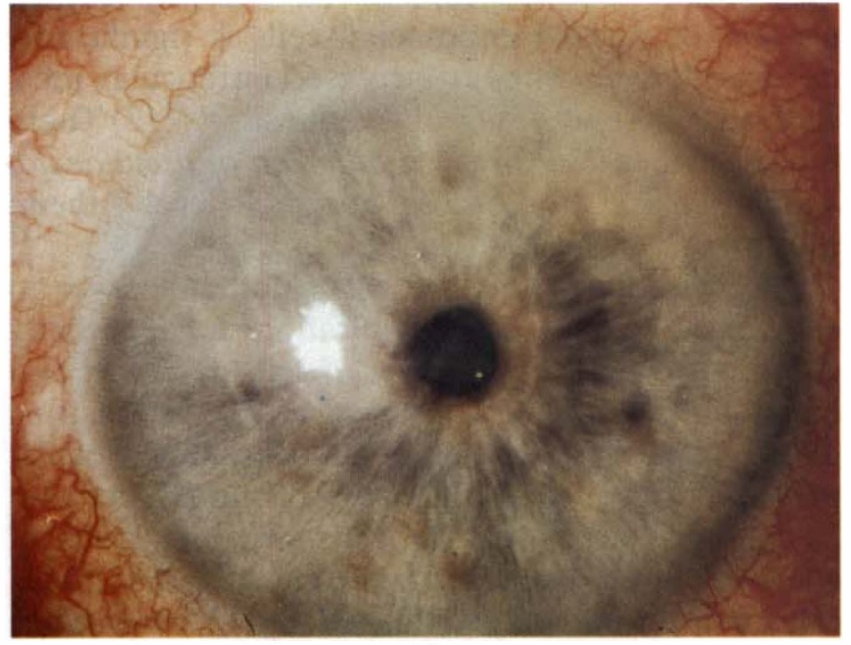

(a)
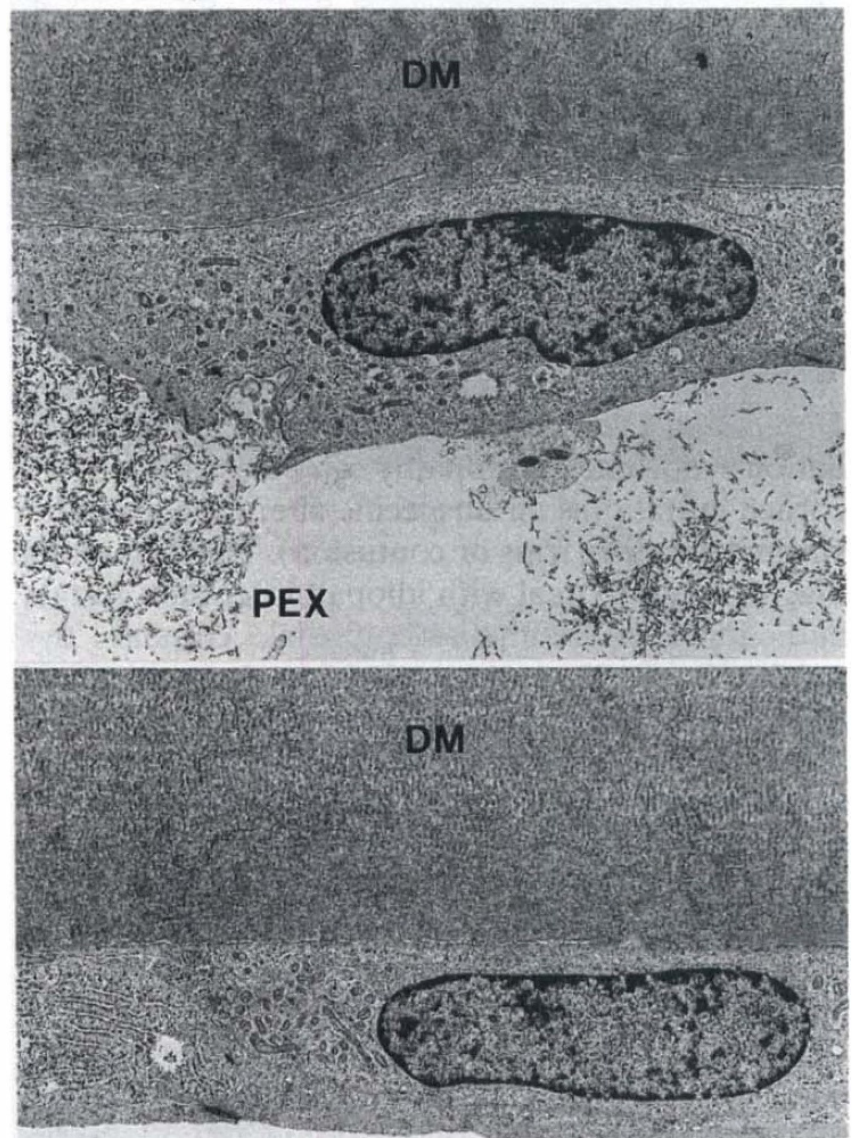

$2 \mu \mathrm{m}$

(c)

Fuchs' corneal dystrophy, which starts centrally and moves peripherally, as well as from bullous keratopathy, e.g. following anterior chamber lens implantation, spreading from the periphery to the centre (Fig. 9). Finally, PEX keratopathy may coexist with other diseases of the corneal endothelium, which explains the spectrum of decompensations.

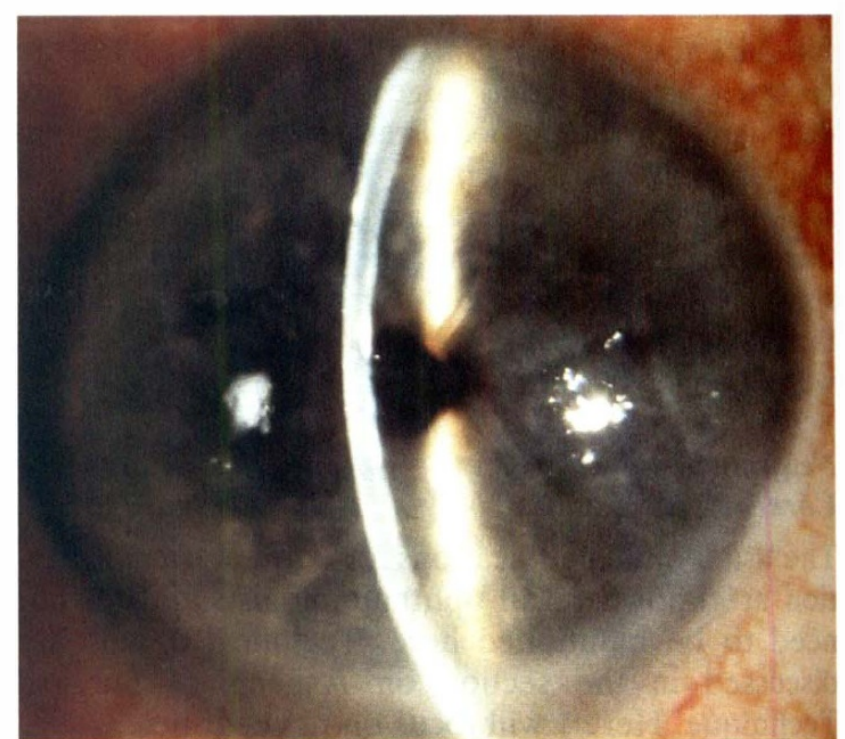

(b)

Fig. 7. Corneal endothelial decompensation with massive intraocular in pseudoexfoliation syndrome (PEX keratopathy) in a 78-year-old man with normal intraocular pressure before penetrating keratoplasty. (a) Opaque, diffuse oedematous cornea: note the small round pupil without evidence of pupillary block. (b) Slit lamp view. (c) Above: Electron micrograph of the corneal button obtained at penetrating keratoplasty. The PEX fibres (PEX) are locally produced by endothelial cells in surface pits of the cell membrane. No PEX fibres are seen inside cells. Below: A neighbouring endothelial cell may be normal in contact with Descemet's membrane (DM). (From Naumann and Schlötzer-Schrehardt. ${ }^{131}$ )

Nuclear Cataract. As the keratopathy in PEX syndrome is often associated with a nuclear cataract, simultaneous corneal transplantation and extracapsular cataract extraction is required. Here it is important to make the diagnosis and be especially aware of the instability of the zonular apparatus in this condition. ${ }^{137-140}$ 


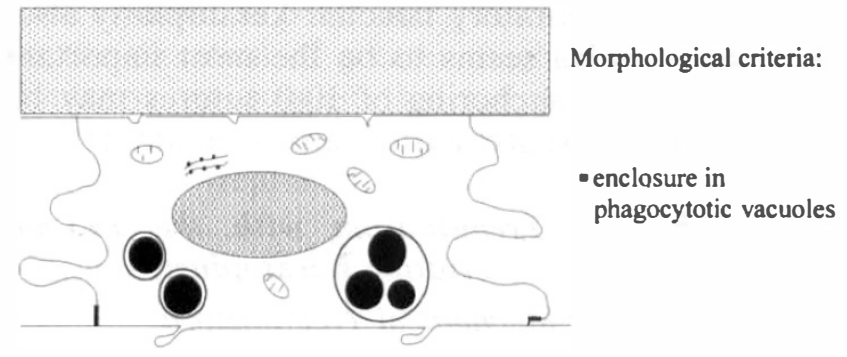

(a)

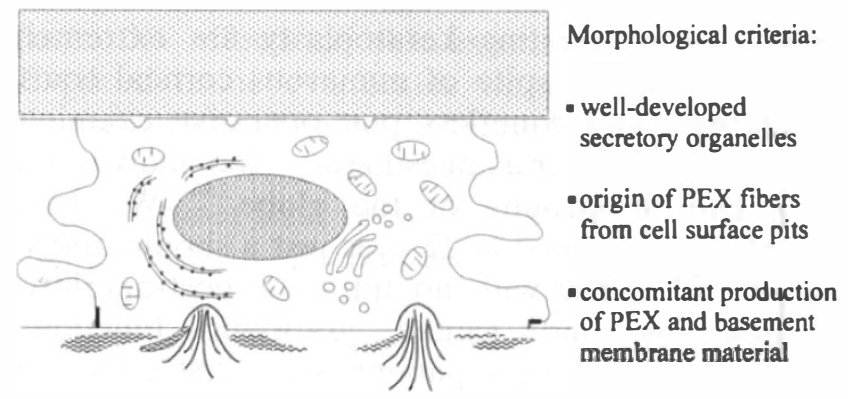

(b)

Fig. 8. Schematic features of pseudoexfoliative (PEX) keratopathy (drawing by Schloetzer-Schrehardt and Naumann). (a) Phagocytosis of melanin granules within endothelial cells. (b) Local production of PEX material in 'surface pits' of corneal endothelium. PEX material is never seen intracellularly.

\section{Münchhausen Syndrome Requiring Corneal Transplantation}

In Münchhausen syndrome the anterior segment of the eye serves only as a signal for the profound psychiatric disease. As ophthalmic surgeons, we pride ourselves on being pragmatic, literally 'handson' people, who certainly try their best also to alleviate the psychological worries of the patients. However, we tend to accept a scar of the cornea as a consequence of somatic disease and tend not to be sceptical if the history of a patient - especially one in the medical profession - is not quite plausible. But we must take self-mutilation into our differential diagnosis and unmask the extravagantly elaborate histories as Münchhausen syndrome if a corneal process takes a totally different course from usual in an otherwise somatically healthy individual.

Surgical strategies require prior treatment by the psychiatrist and their continued assistance, as well as the patient's co-operation. In our series, two physicians and two nurses required penetrating and two lamellar corneal transplantations. The longrange outlook in Münchhausen syndrome tends to be frustrating - despite exhaustive efforts. ${ }^{141}$

\section{Central Autologous Corneal Transplantation as 'Access' for Cataract Extraction}

Corneal transplantation may serve as the door for lens surgery in pronounced microcornea. ${ }^{142,143}$ This 'open-sky' approach was useful in 5 eyes. ${ }^{143}$ In corneal diameters of 5-8 $\mathrm{mm}$ and a dense cataracta brunescens/nigra or a piriform shape of cataract, the

Table II. Differential diagnosis of Fuchs' endothelial corneal dystrophy and pseudoexfoliation keratopathy

\begin{tabular}{lcc}
\hline & $\begin{array}{c}\text { Fuchs' } \\
\text { corneal dystrophy }\end{array}$ & $\begin{array}{c}\text { Pseudoexfoliation } \\
\text { keratopathy }\end{array}$ \\
\hline Cornea guttata & +++ & + \\
Iris atrophy & - & $+\rightarrow+++$ \\
Melanin dispersion & - & ++ \\
Location & Central & Diffuse \\
Endothelial loss & +++ & ++ \\
Secondary glaucoma & $(+)$ & ++ \\
Nuclear cataract & ++ & ++ \\
\hline
\end{tabular}

use of ultrasonic phacoemulsification or aspiration via any type of 'limbal incision' was impossible.

\section{Contraindications to Keratoplasty}

At first glance the concept of contraindications to keratoplasty may seem far fetched, but there are definite contraindications, not only in uncontrolled glaucoma.

\section{Processes in Front of Bowman's Lamina}

Here corneal transplantation is not required. Blunt dissection from above the rugged structure of Bowman's lamina is sufficient. Re-epithelisation achieves a 'restitutio ad integrum' within a week. ${ }^{93}$

\section{Sclerocornea}

Reports in the literature on attempts at penetrating keratoplasty in this extreme anomaly of the anterior segment are sadly disappointing and usually lead to atrophy of the globe and phthisis bulbi. In the 3 unoperated children under my care, it is surprising how relatively well they function with their residual vision. They all recognise colour; one 6-year-old boy uses his tricycle without help on the pavement.

\section{Peters' Anomaly in Microcornea}

Here, optical sector iridectomy is an alternative option! Reports in the literature indicate that the

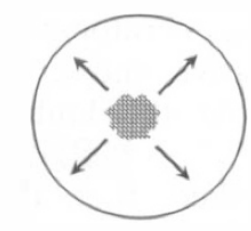

$$
\begin{gathered}
\text { FUCHS' comeal dystrophy } \\
\text { cornea guttata } \\
\text { central }
\end{gathered}
$$
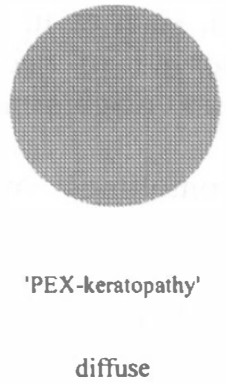

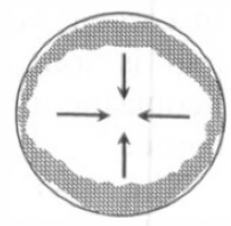

Bullous keratopathy with AC lens implant peripheral
Fig. 9. Differential diagnosis of corneal endothelial decompensation: Classical Fuchs' corneal dystrophy starts in the centre and spreads peripherally. Secondary endothelial decompensation with anterior chamber lens implant usually begins in the limbal region. PEX keratopathy tends to involve the cornea diffusely. 
results of penetrating keratoplasty are extremely disappointing. In spite of numerous corneal transplantations and countless post-operative examinations - under general anaesthesia! - too many of the eyes end in atrophy of the globe. ${ }^{144} \mathrm{We}$ have therefore performed in 22 eyes just a simple optical sector iridectomy with no intra- or post-operative complication and gained gratifying functional results. ${ }^{145}$ As all these patients were first seen with manifest nystagmus the functional results are not fabulous, but much better than the reported results after penetrating keratoplasty. Perhaps the situation can be summarised by stating that 'the better can be the enemy of the good'.

\section{SOME ASPECTS OF SURGICAL TECHNIQUES}

Nuances of surgical technique are of particular importance in the delicate procedure of corneal transplantation..$^{33}$ The principal goals are: (1) ensure water-tight wound closure at the end of the procedure to restore the anterior chamber completely without obtaining anterior synechiae, (2) to keep damage to the graft endothelium to a minimum, and (3) to reduce the risk of post-operative complications such as wound dehiscence, immunological allograft reaction and suture-induced shortterm and long-term residual astigmatism.

\section{Surgical Significance of Bowman's Lamina in Corneal Surgery}

In Bowman's own words, written in 1847, 'the anterior elastic lamina of the cornea is $1 / 1200$ to $1 / 1000$ inch thick and the maintenance of its exact curvature is of primary importance to vision'; 'this arrangement might, I imagine, be shown on mechanical principle to be the best possible for the maintenance of the convexity of the front of the cornea ${ }^{57}$ Consequently, it is a determining factor for the refractive power of the cornea and particularly of any astigmatism. It is the most important structure to be considered in the inevitable scarring after photorefractive keratectomy. ${ }^{146}$ It is also resistant to corneal oedema, such as in bullous keratopathy, and is long preserved in proliferative and even neoplastic processes originating from the limbus cornea. $^{93}$

The fact is sometimes overlooked that the presence or absence of Bowman's lamina also determines the anchoring of the 10-0 nylon sutures. ${ }^{147,148}$ If post-operatively a loosening of the 10-0 nylon suture occurs it is always in areas where Bowman's lamina was absent. If Bowman's lamina is missing in parts of the patient's cornea, this is considered a contraindication for a running suture and we try to modify the width of the suture bite for single interrupted sutures in such a way that the suture runs through areas of Bowman's lamina if possible. In preparatory lamellar keratoplasty also, Bowman's lamina seems to be the most important structure. $^{93}$ The anchoring of 10-0 sutures may be deficient in its absence, particularly in children. ${ }^{149,150}$

\section{Non-mechanical Trephination with the $193 \mathrm{~nm}$ Excimer Laser in Penetrating Keratoplasty}

\section{Disadvantages of Mechanical Trephination}

All methods of mechanical trephination are associated with three principal disadvantages: (1) The mechanical force leads to deformation of the tissue and therefore to some degree of deviation of the intended cut. (2) This deformation differs between donor and recipient cornea, resulting in a 'vertical tilt' (Fig. 10). (3) As all surgeons know, the fitting of the donor tissue into the malleable recipient cornea is extremely difficult to achieve in perfect symmetrical fashion. Therefore some degree of asymmetrical placement and rotation of the donor tissue in situ of the patient's cornea leads to 'horizontal torsion' (Fig. 10). Since von Hippel (1888) developed a trephine with a clockwork motor ${ }^{151}$ many other manual and motor-driven trephines have been developed. ${ }^{152-154}$ However, the principal difficulty remains. We therefore disagree with Olson, ${ }^{155}$ who believes that 'future

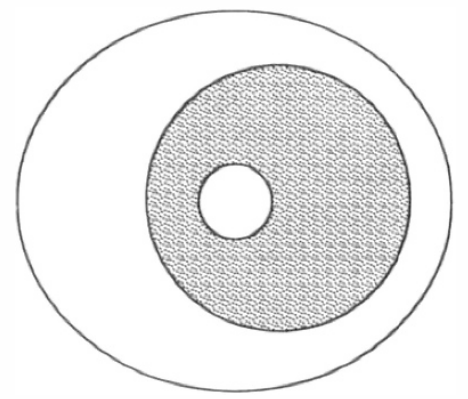

Decentration
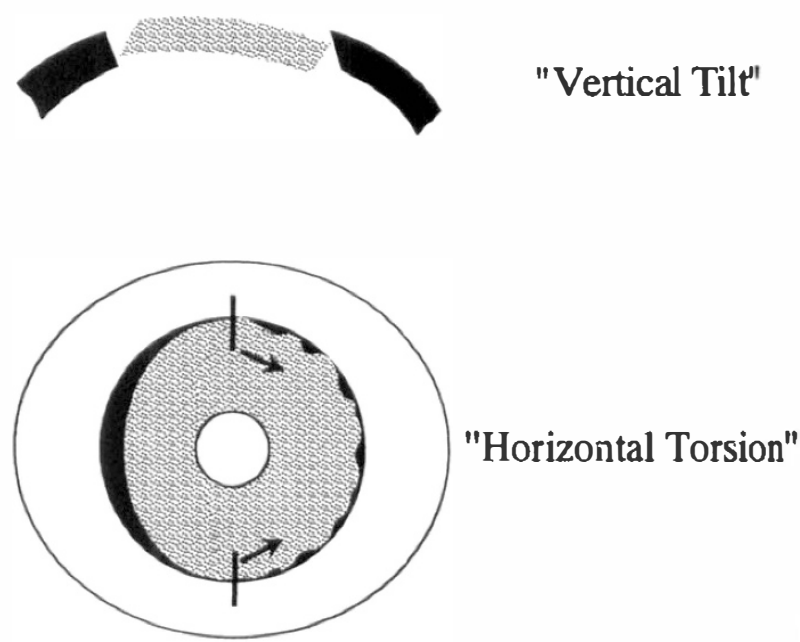

Fig. 10. Typical deformations in conventional penetrating keratoplasty. Mechanical trephination by hand or motordriven may lead to decentration of the graft, 'vertical tilt' and/or 'horizontal torsion' (bottom). 
development in penetrating keratoplasty may move in the direction of greater mechanisation'. On the contrary, we suggest that on theoretical grounds alone, the future will be reached by non-mechanical methods of trephination. ${ }^{156}$

Arguments for and Principles of a Non-mechanical Approach with $193 \mathrm{~nm}$ Excimer Laser Trephination

For our experiments and later applications to patients, we used the Meditech $193 \mathrm{~nm}$ excimer laser. ${ }^{156-160}$ Tissue behind a metal mask is protected from the effects of the excimer laser (Fig. 11). Exposed tissue evaporates without mechanical or thermal effects. The invisible laser beam is guided by a red helium-neon aiming laser beam, but the effect of the excimer laser itself is visible at the edge of the metal mask by its fluorescence. Exposure of the corneal tissue at the edge of the metal mask is under direct microscopic control and the procedure can be interrupted at any stage.

Arguments for using the excimer laser are the following: (1) As there is no mechanical contact
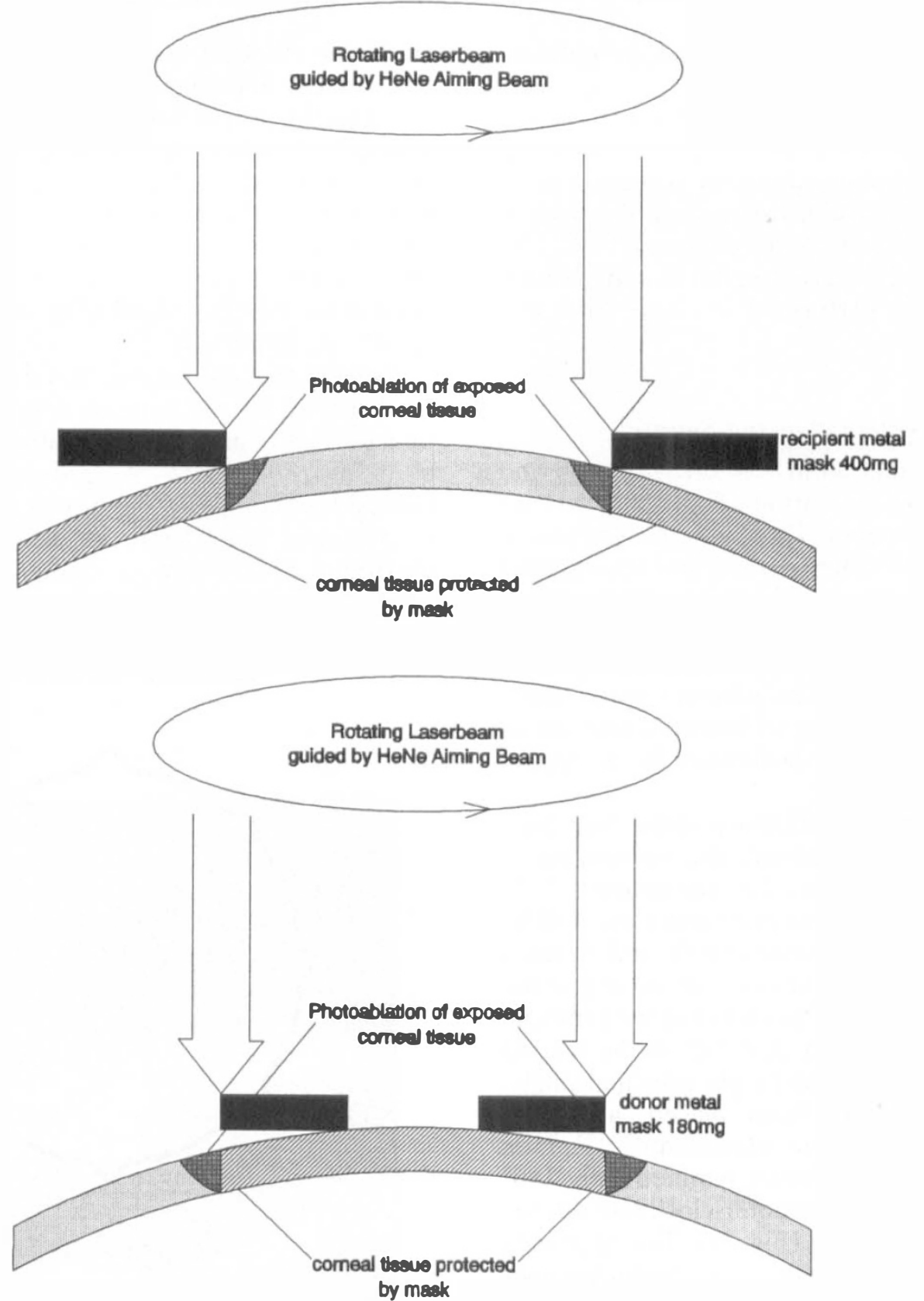

Fig. 11. Principle of non-mechanical trephination with the $193 \mathrm{~nm}$ excimer laser along a metal mask. Half of the $1.5 \mathrm{~mm}$ beam is on the mask, the other half on exposed cornea. Tissue behind the mask is protected. Features of the cut are practically identical for the patient's and the donor cornea. Above: Patient's cornea with open recipient mask. Photoablation of corneal tissue at the inner edge of the metal mask results in a penetrating cut until aqueous prevents further penetration. Below: Donor cornea (from a whole eye or a corneoscleral ring fixed in an artificial anterior chamber) with donor mask. Photoablation is performed at the outer edge of the mask. 
during cutting, practically no deformity of the tissue is possible (the weight of the metal mask ranges from 90 to $400 \mathrm{mg}$ ). (2) If the donor and recipient corneas are each placed horizontally beneath the perfectly horizontally placed metal mask, the wound surfaces of graft and patient are practically identical. (3) As the entire procedure is visible under the microscope, centration is facilitated. (4) Any shape of the trephine opening can be chosen. This is in contrast to mechanical methods that favour a circular outline of trephination. (5) As soon as the anterior chamber is opened, the cutting process is stopped by the outflow of aqueous. ${ }^{156-160}$

Before the procedure was applied to patients, extensive animal experiments on pigs' eyes were performed to verify the technical details; trephination had to be checked, mutagenic effects on corneal tissue had to be ruled out, both on corneal and on other extra- and intraocular tissues, and the woundhealing mechanism had to be analysed. ${ }^{157-159}$ On 16 June 1989 non-mechanical trephination by $193 \mathrm{~nm}$ excimer laser was performed on the first two patients. ${ }^{160,161}$

\section{Non-mechanical Trephination and Suturing}

Trephination is possible from both the whole eye and a corneoscleral ring measuring $16 \mathrm{~mm}$, fixed in an artificial anterior chamber. The metal mask is placed on the centre of the donor cornea and the excimer laser guided along the outside of the mask, which today has seven orientation teeth of $0.15-0.2 \mathrm{~mm}$, in addition to a more prominent orientation tooth of $0.2-0.4 \mathrm{~mm}$ (Figs. 12-14). The patient's mask shows eight corresponding notches of identical size on its inner side. Centration is facilitated by a central opening in the donor mask.

Non-mechanical trephination is possible only until the anterior chamber is opened; the outpouring of aqueous stops further cutting. The remaining $0-10 \%$ of the deeper corneal stroma must therefore still be cut by scissors. The orientation teeth and notches allow fitting of the transplant tissue according to the 'key-lock principle'. ${ }^{162-167}$ Placement of the principal sutures is greatly facilitated, particularly the second principal suture. After the first eight principal single, interrupted sutures have been placed, a double running suture according to Hoffmann ${ }^{156,168,169}$ is inserted. The knots are placed symmetrically $180^{\circ}$ apart after clockwise and counter-clockwise adjustment of the running sutures (Fig. 14). This approach also allows a combination with extracapsular cataract extraction as a 'triple procedure'.

We used a slow 'step-by-step' and 'wait-and-see' approach in the clinical application of non-mechanical trephination to our patients. Since 1989 numerous details have been further refined (Table III). These concern changing the shape of the trephina-
Table III. Steps in the development of non-mechanical trephination with the $193 \mathrm{~nm}$ excimer laser

\begin{tabular}{|c|c|}
\hline 1989-90 & Elliptical mask, MEL 50, repeat rate 30/s \\
\hline Nov. 1991 & Add 4 orientation teeth, MEL 60 , repeat rate $25 /$ \\
\hline Jan. 1992 & Round, 4 orientation teeth $(0.15 \times 0.3 \mathrm{~mm})$ \\
\hline Feb. 1992 & Double running suture (Hoffmann) \\
\hline Apr. 1992 & Artificial anterior chamber (Krumeich) \\
\hline May 1992 & Round, 8 orientation teeth $(0.15 \times 0.3 \mathrm{~mm})$ \\
\hline June 1992 & Add 1 'marker' $(0.2 \times 0.4 \mathrm{~mm})$ \\
\hline Sept. 1992 & Automatic rotation of donor tissue \\
\hline Sept. 1992 & Double running suture with knots $180^{\circ}$ apart \\
\hline Oct. 1992 & $\begin{array}{l}\text { Excimer vs conventional penetrating keratoplast) } \\
\text { in Fuchs' dystrophy and keratoconus }\end{array}$ \\
\hline 1993 & Horizontal positioning of the limbal plane \\
\hline Dec. 1993 & Harmonising of donor/recipient corneal topography \\
\hline
\end{tabular}

tion from elliptical to circular with orientation teeth, the number and shape of the orientation teeth and notches, the proper diameters, the use of an artificial anterior chamber, the automatic rotation of the donor tissue, the achievement of perfect horizontal placement of the donor and patient's cornea by the focusing device of the excimer laser and of the mask by total reflection of the coaxial microscope light. It is obvious that the 'devil is in the details' and the details are important.

Patients and Indications. Between June 1989 and 1994 a total of 124 patients with avascular corneal opacities and (since 1993) keratoconus were treated as described below. A prospective randomised clinical trial comparing results of transplantation for keratoconus $(8.0 / 8.1 \mathrm{~mm}$ in diameter) and Fuchs' dystrophy $(7.5 / 7.6 \mathrm{~mm}$ in diameter) was started in 1993 and is in progress.

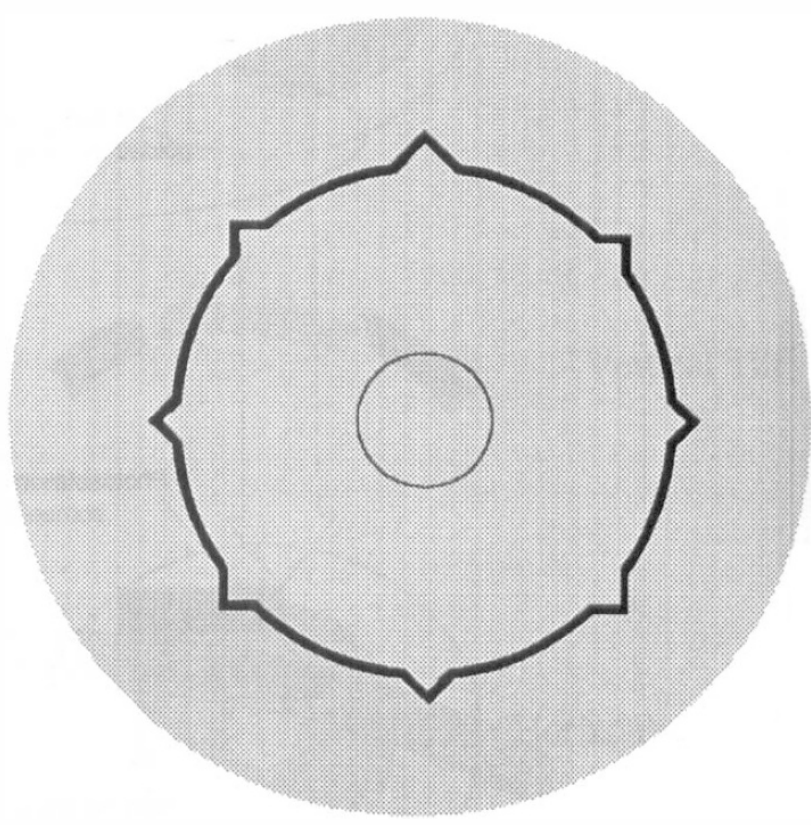

Fig. 12. Principle of non-mechanical trephination with the $193 \mathrm{~nm}$ excimer laser along the edge of a metal mask in penetrating keratoplasty. The horizontal schema showing eight orientation teetch/notches (one $0.2 \times 0.4 \mathrm{~mm}$ and seven $0.15 \times 0.3 \mathrm{~mm}$ ). Currently the graft diameter is $0.1 \mathrm{~mm}$ larger. Standard diameter for keratokonus is $8.0 /$ $8.1 \mathrm{~mm}$; for Fuchs' corneal dystrophy 7.5/7.6 mm. 


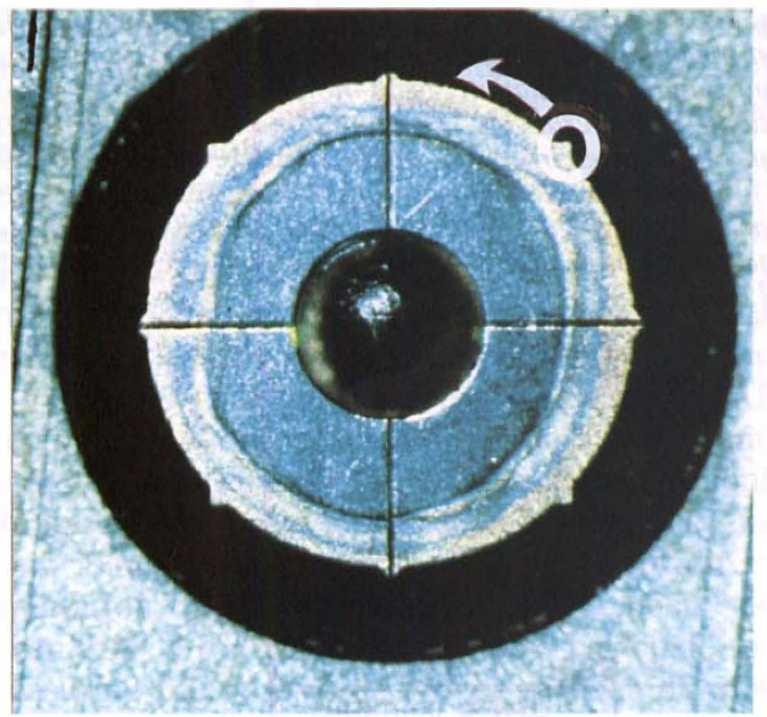

(a)

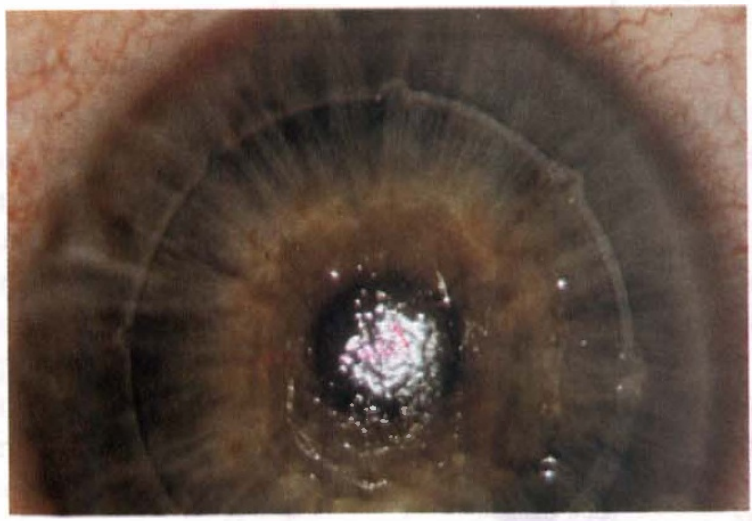

(c)

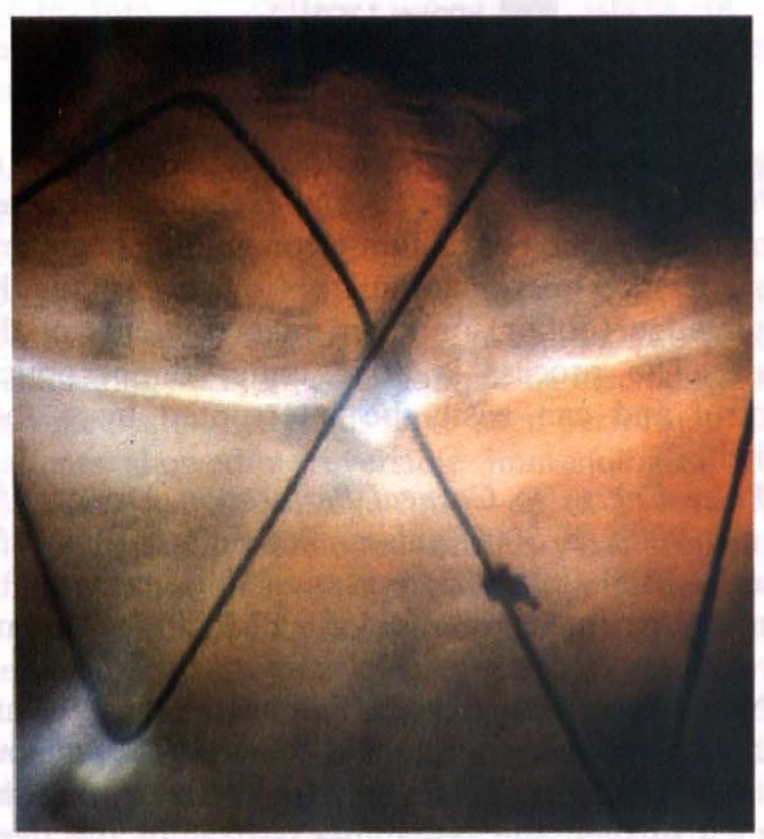

(e)

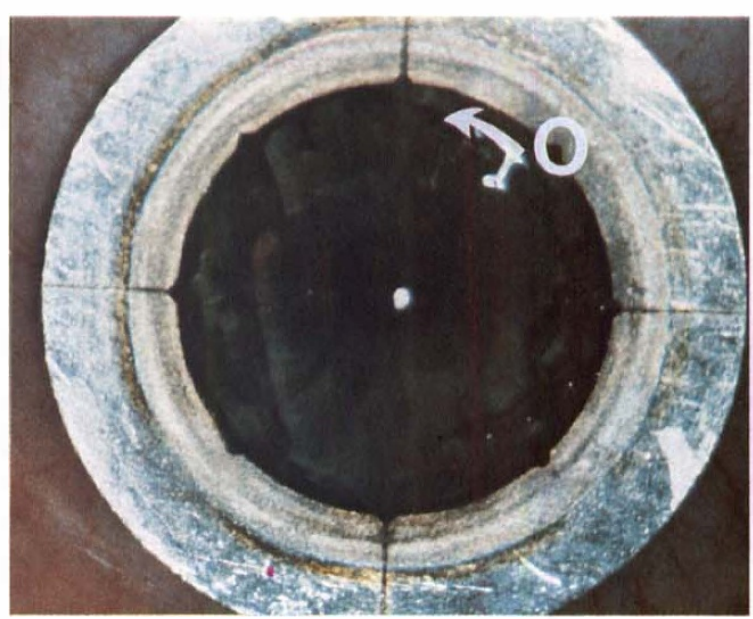

(b)

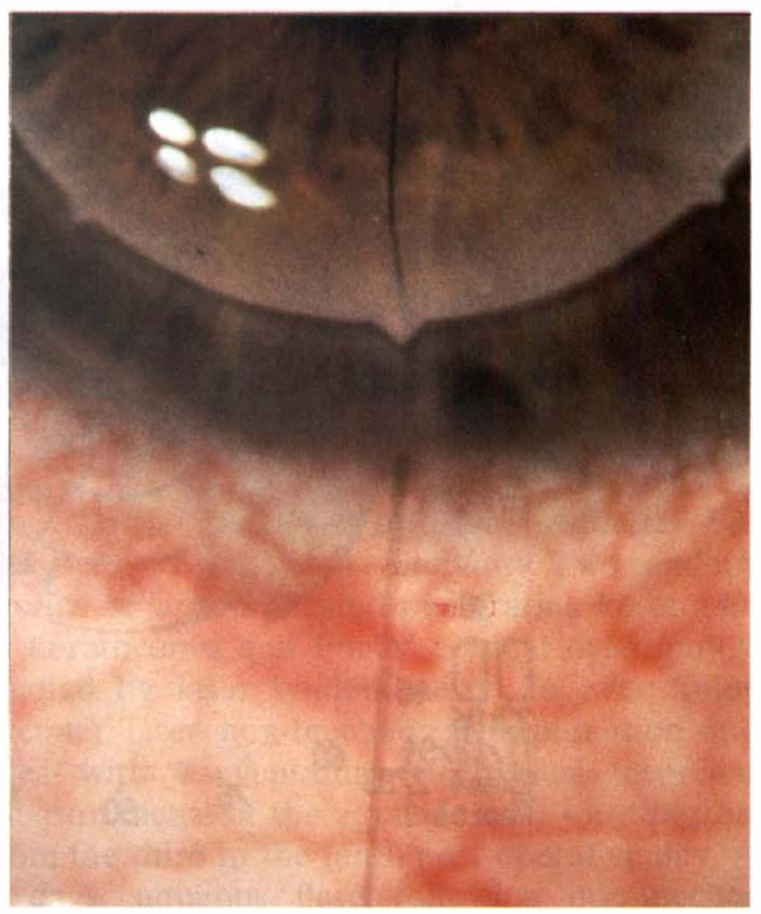

(d)

Fig. 13. Practical steps of non-mechanical trephination with the $193 \mathrm{~nm}$ excimer laser along a metal mask. (a) Donor metal mask with eight orientation teeth on a corneoscleral ring fixed in an artificial anterior chamber. The white ring indicates the $1.5 \times 1.5 \mathrm{~mm}$ laser beam on the outer edge of the mask automatically rotating (arrow). (b) The patient metal mask. The invisible $193 \mathrm{~nm}$ excimer laser beam width of $1.5 \mathrm{~mm}$ is rotated manually along the inner edge of the mask by the surgeon using a joy-stick. The location of the beam is indicated by the red helium-neon laser guiding beam and/or fluorescence from the mask surface. The open mask is $8.0 \mathrm{~mm}$ in diameter and has eight corresponding orientation notches. (c) The patient's cornea shows the orientation notches at the end of trephination. $(d)$ Placement of a 10-0 nylon suture through the principal orientation tooth-notch $(0.2 \times 0.4 \mathrm{~mm})$. (e) Typical orientation tooth-notch $(0.15 \times 0.3 \mathrm{~mm})$ combination post-operatively with double running suture in place. 


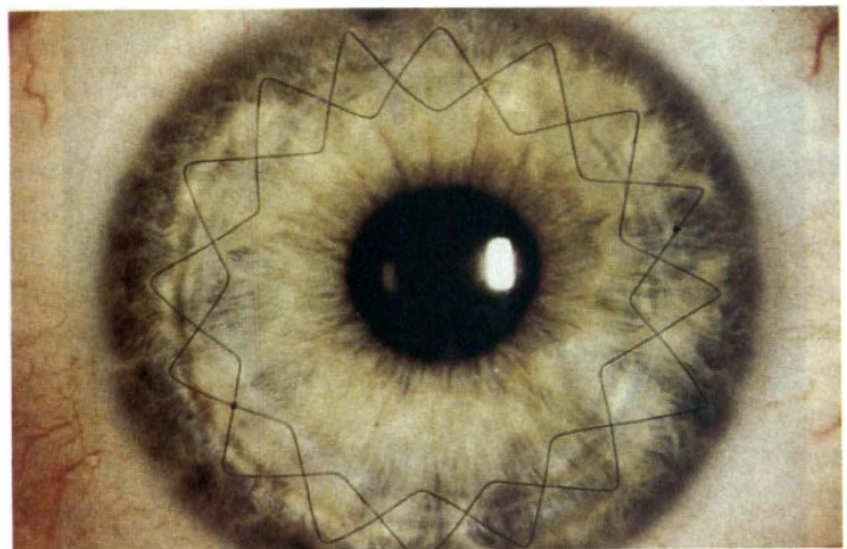

Fig. 14. Corneal graft $(8.0 / 8.1 \mathrm{~mm})$ for keratoconus after non-mechanical trephination with the $193 \mathrm{~nm}$ excimer laser using eight orientation teeth-notches in a 16-year-old patient. Pre-operatively the ophthalmometer showed more than 60 dioptres irregular, visual acuity $-9.0=-3.0 \mathrm{A90^{ \circ }}$ 0.1 . (a) The double running suture in place; knots are $180^{\circ}$ apart. $-3.0 \mathrm{sph}=$ cyl. $-1.0 \mathrm{A40^{ \circ }}=0.8$. (b) Corneal topography after suture removal; $-2.0 \mathrm{sph}=\mathrm{cyl} .-0.5 \mathrm{A10^{ \circ }}$ $=1.0$.

(a)

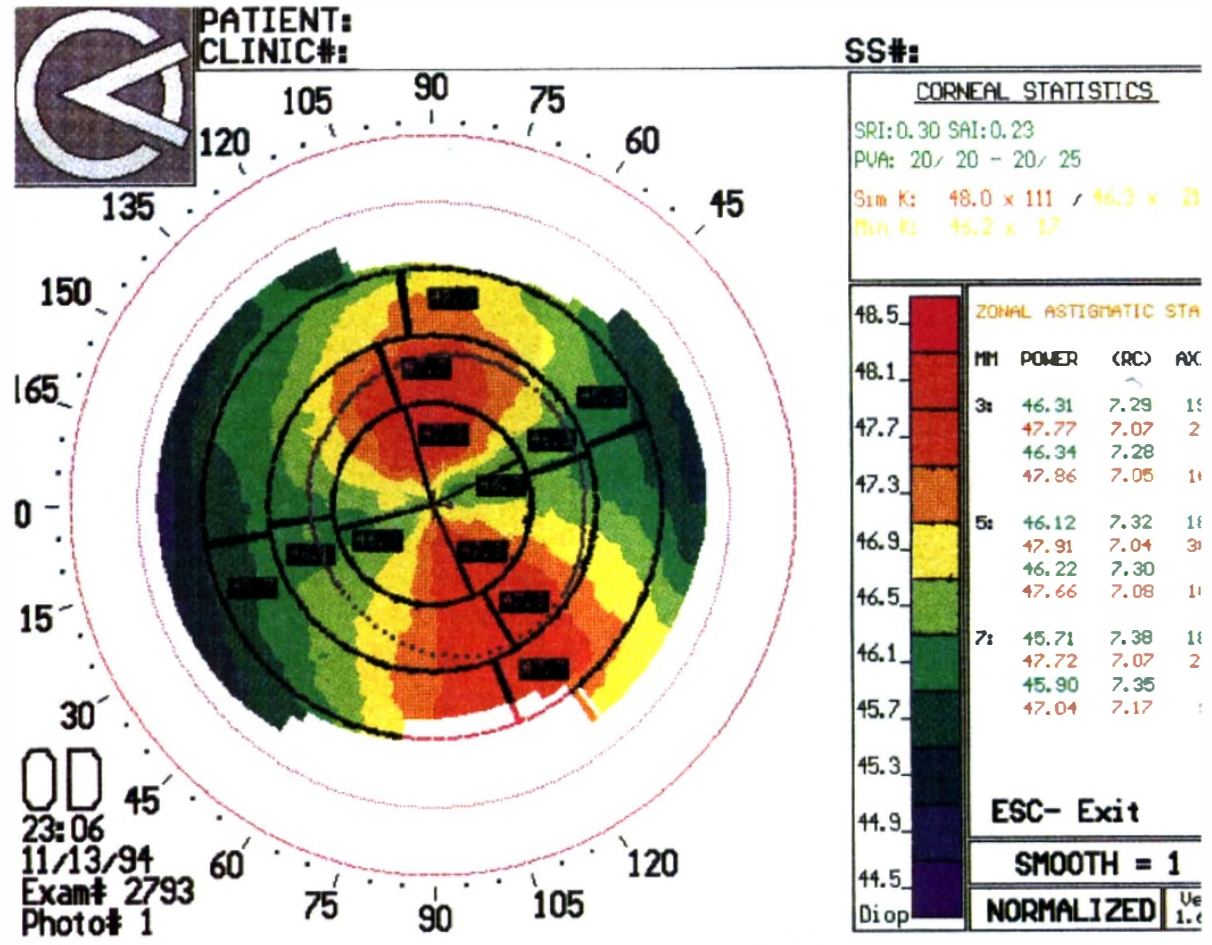

(b)

General Surgical Aspects. All 124 penetrating keratoplasties were done by myself - with the exception of cases 3 and 10 . Non-mechanical trephination using the $193 \mathrm{~nm}$ excimer laser was performed along a metal mask. General anaesthesia was used except for one patient. After insertion of a lid speculum sutures were placed into the superior and inferior rectus muscles. Since November 1993 horizontal positioning of the limbal plane of the patient's cornea has been achieved with the help of the focusing device of the excimer laser. Horizontal positioning of the metal mask was evident when there was total reflection of the coaxial light from the OPMI-IV Zeiss operating microscope.

Technical Data. From June 1989 to October 1990 we used the Aesculap-Meditec (Heroldsberg, Germany) Phönix MEL $50193 \mathrm{~nm}$ excimer laser with a repetition rate of 30/s. Since November 1990 we have used the Phönix MEL 60 with a repetition rate of $25 / \mathrm{s}$. The invisible $1.5 \times 1.5 \mathrm{~mm}$ excimer laser beam is marked by the red helium-neon guiding beam and moved with a micromanipulator (joy-stick) along the outer edge (donor) or inner edge (patient) of the mask. The process is done under direct optical control and can easily be interrupted by a foot switch.

Pulse Energy to Corneal Perforation. Donor: 15$22 \mathrm{~mJ} ; 9000 \pm 3000$ pulses. Patient's cornea: 15$25 \mathrm{~mJ} ; 6500 \pm 2000$ pulses. (Measurement by pyroelectric measuring device PM 50M, Radiant Dyes Laser Accessories, Germany.)

Non-mechanical trephination with the $193 \mathrm{~nm}$ excimer laser takes about 5-7 minutes. As aqueous prevents the ultraviolet light from penetrating the cornea further, the remaining $0-10 \%$ of the deep corneal stroma has to be cut by scissors. Eight 
principal sutures, later removed, are placed through the orientation notches and teeth and a double running suture after Hoffmann with opposite symmetrical knots is placed.

Configuration of the Metal Mask. The weight of the donor mask is $90-180 \mathrm{mg}$ and it is $0.25-0.5 \mathrm{~mm}$ thick. The weight of the patient's mask is $200-400 \mathrm{mg}$ and is $0.25-0.5 \mathrm{~mm}$ thick. Between June 1989 and December 1990 a total of 22 elliptical masks between $6 \times 7$ and $7 \times 8 \mathrm{~mm}$ diameter were used. ${ }^{161}$ After November 1991 only circular masks $6.5-8.0 \mathrm{~mm}$ in diameter with changes in the direction and configuration of the orientation teeth and notches were used. Since summer 1992 only outward-directed orientation teeth and notches have been used: seven $0.15 \times 0.3 \mathrm{~mm}$ teeth and one 'principal' tooth measuring $0.2 \times 0.4 \mathrm{~mm}$. ${ }^{162}$ For reasons of wound safety the outer diameter of the donor mask edge is $0.1 \mathrm{~mm}$ larger than that of the patient's cornea.

\section{Preliminary Results}

Between 1989 and 1994 non-mechanical trephination has been performed using the $193 \mathrm{~nm}$ excimer laser in 124 patients who required corneal transplantation for non-vascularised corneal processes. To avoid any unpleasant surprises, in the first year only 2 patients and in the second year only 20 patients were operated on. In the course of the 5 years no unexpected complications developed and the results are at least as good as those achieved by mechanical trephination.

Intra- and Post-operative Complications. With higher energy levels insignificant thermal epithelial changes can occur; this does not happen with the application of 25 hertz. Minimal traces of iris microhaemorrhage may be observed at the site of corneal perforation.

Wound Healing. Re-epithelisation requires an average of 2 days and wound closure is unremarkable.

Due to our very slow eclectic approach only a relatively small number of consecutive prospective penetrating keratoplasties comparing mechanical and non-mechanical methods have been performed. Two patients showed a reversible immunological graft reaction after an average follow-up of 2 years. Two diabetic patients developed transitory bacterial ulcers under sub-optimal post-operative care elsewhere with contact lenses. In the initial phase, for the most part very old patients were considered as candidates for the procedure, but since 1993 patients with keratoconus have been included. Centration of the graft is superior to that achieved with mechanical trephination. A learning curve for reduced astigmatism can be demonstrated. Post-operative astigmatism, even with sutures still in place, seems to be more regular than after mechanical trephination (see below).

\section{Further Potential Advantages}

'Open Eye'. Trephination of an extremely soft eye makes mechanical trephination difficult or even impossible - even when using a really sharp mechanical trephine. If the anterior chamber is filled with Healon and seeping of aqueous out of the defect is prevented, the placement of the almost weightless mask $(200 \mathrm{mg})$ on this eye facilitates the edging of an outline for the trephination and has obvious advantages.

Infectious Processes of the Cornea. 'Disinfection' of the cut edges in e.g. amoebic keratitis may be possible. As Garner ${ }^{170}$ has pointed out in his clinico-pathological correlation of 30 cases of amoebic keratitis, it is impossible to determine clinically the extent of invasion of the amoebae into the patient's cornea.

In 4 patients we used non-mechanical trephination in order to avoid smearing of the infectious elements with a mechanical trephine, gaining excellent results. The same holds true for other forms of infectious keratitis which do not respond to medical therapy. ${ }^{93,171-173}$

Reduction of Leakage of Blood-Aqueous Barrier Following Penetrating Keratoplasty. Two randomised groups of uncomplicated penetrating keratoplasties in keratoconus and Fuchs' corneal dystrophy were studied by laser tyndallometry: 26 eyes following excimer laser non-mechanical trephination and 26 eyes with conventional mechanical trephination. Measurements of the aqueous flare were performed from the third to the tenth post-operative day. After 6 days, aqueous flare following non-mechanical trephination by excimer laser keratoplasty was significantly less pronounced than with conventional mechanical trephination (Table IV). Comparison of the advantages and disadvantages of conventional and non-mechanical trephination has confirmed our working hypothesis that non-mechanical trephination has potential for the future.

Table IV. Aqueous flare following excimer laser versus conventional mechanical penetrating keratoplasty: early postoperative course

\begin{tabular}{lccc}
\hline & \multicolumn{2}{c}{ Aqueous flare (photon counts/ms) } \\
\cline { 2 - 3 } Post-operative & $\begin{array}{c}\text { Excimer } \\
(n=26)\end{array}$ & $\begin{array}{c}\text { Conventional } \\
(n=30)\end{array}$ & $\begin{array}{c}\text { Significance } \\
(p \text { value })\end{array}$ \\
follow-up & $21.1 \pm 5.4$ & $25.9 \pm 8.9$ & 0.06 \\
3rd day & $16.1 \pm 4.9$ & $21.2 \pm 5.7$ & 0.02 \\
5th day & $12.6 \pm 3.4$ & $17.5 \pm 5.5$ & 0.005 \\
7th day & $9.3 \pm 2.2$ & $12.8 \pm 3.2$ & 0.001 \\
\hline 9th day & &
\end{tabular}

After Küchle et al. ${ }^{20}$ 

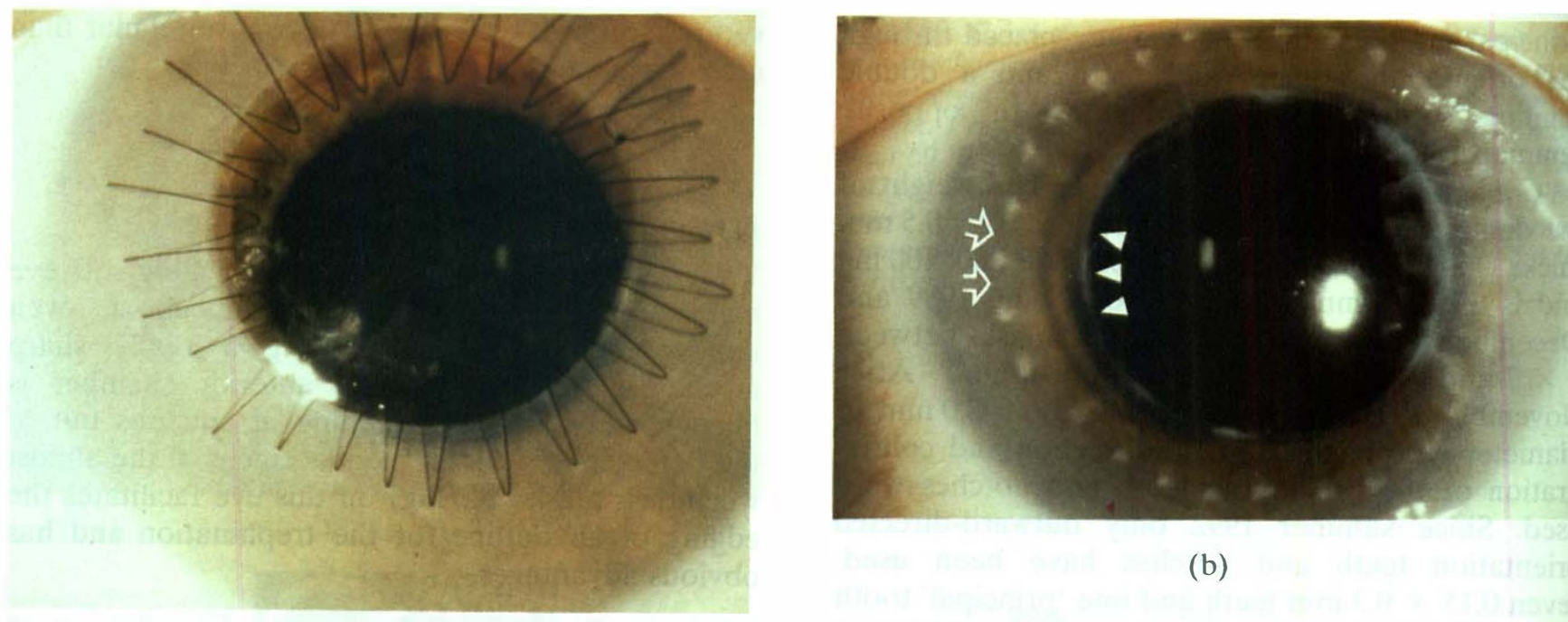

(b)

(a)

Fig. 15. Clearing of the cornea following penetrating keratoplasty in Maroteaux-Lamy muco polysaccharidosis VIA in a 7year-old girl. (a) Clear corneal graft of $6.2 \mathrm{~mm}$ with a running suture in place 3 months after surgery. Note that the patient's cornea is dense and opaque up to the wound edge. (b) After 2.5 years there is distinct clearing of the patient's cornea beyond the area of suture tract (arrows). The graft edge is indicated by arrowheads. (From Naumann and Rummelt. ${ }^{177}$ )

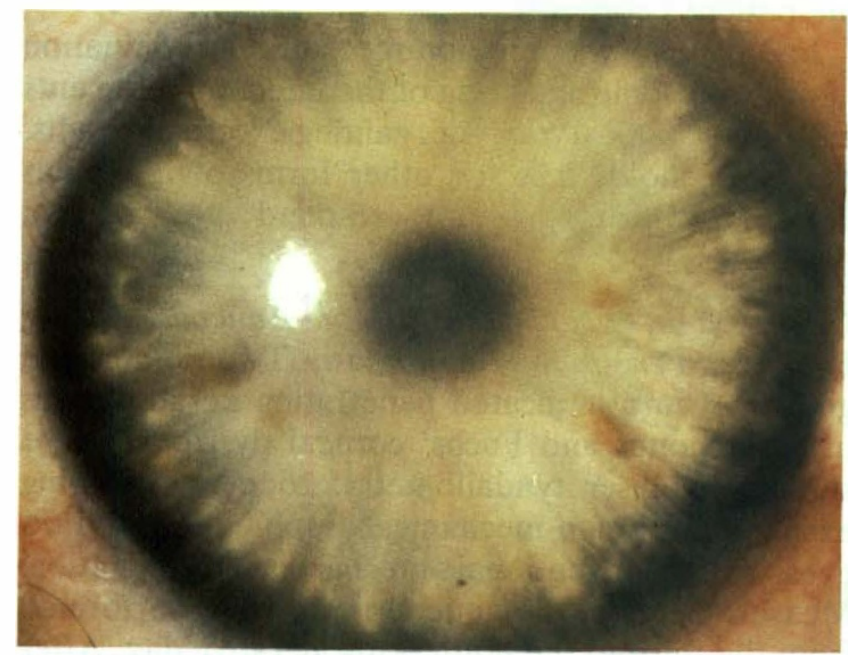

(a)

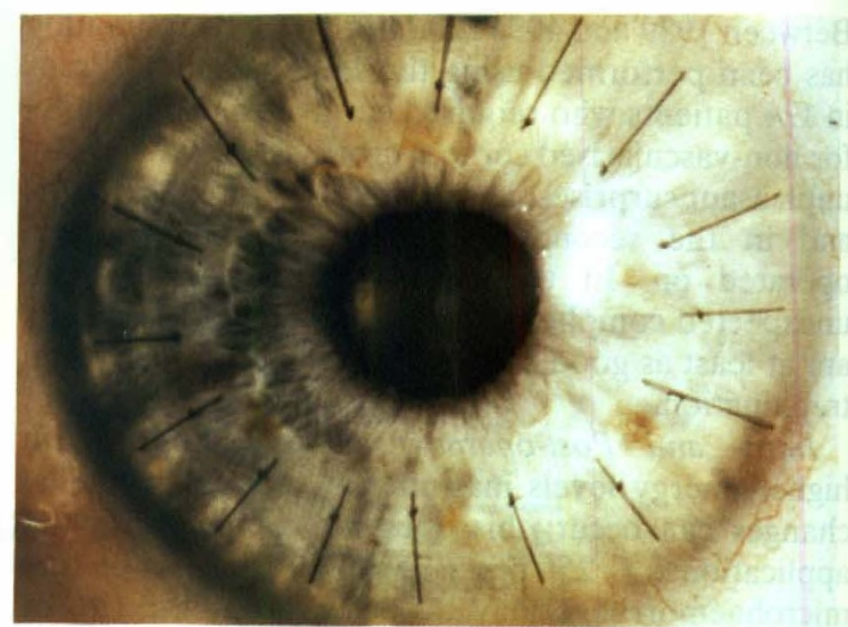

(b)

Fig. 16. Clearing of a patient's cornea following elliptical penetrating keratoplasty (PK) for diffuse corneal endothelial decompensation. This was the first case done with non-mechanical trephination in June 1989. (a) Diffuse corneal oedema from limbus to limbus. (b) Two years after elliptical PK $(8.0 \times 7.0 \mathrm{~mm} / 8.1 \times 7.1 \mathrm{~mm})$ by non-mechanical trephination with the excimer laser the patient's cornea had cleared completely. $($ Ophthalmometer $+2.0=c y l-2.0$ A70 $)$. (Same patient as reported by Lang and Naumann. ${ }^{160}$ )

\section{GRA FT-VERSUS-HOST EFFECT IN CORNEAL TRANSPLANTATION}

\section{Clearing of the Patient's Cornea}

Our medical colleagues in liver transplantation today talk about 'chimerism', that is the distribution of donor cells away from the location of the main bulk of the transplanted organ. ${ }^{174,175}$ We usually do not pay much attention to these effects of the corneal graft on the patient's cornea. But as ophthalmologists, we are able to observe both the graft and the adjacent host tissue and the interface under high magnification: By observing more closely we may learn more about the interaction between graft and host following corneal transplantation.

\section{Maroteaux-Lamy Mucopolysaccharidosis VI}

After penetrating keratoplasty in 4 eyes of 3 patients the corneal grafts remained clear in a follow-up of from $2 \frac{1}{2}$ to 5 years. We observed in 3 of these patients after 2 years a striking clearing of the cornea adjacent to the graft. ${ }^{176,177}$ This phenomenon, so evident biomicroscopically, has not been studied histopathologically. The following possibilities might 
be discussed as a potential explanation: migration and proliferation of corneal endothelium and/or stromal keratocytes from the graft into the patient's cornea, or seeping of enzymes from the same type of cells from the graft to the donor tissue (Fig. 15).

Diffuse Bullous Keratopathy from Limbus to Limbus Photographs of 38 patients before and from 4 to 47 months after penetrating keratoplasty ${ }^{178}$ showed a striking clearing of the patient's cornea in $31(81 \%)$ cases (Fig. 16).

\section{Immunological Allograft Reaction}

Immunological allograft reaction would be expected in all eccentric tectonic grafts. However, in some of these eccentric grafts, immunological graft reactions do not develop (Fig. 6b). All the other eccentric graft locations allow us to study the typical chronic endothelial immune reactions attacking the graft corneal endothelium, leading to corneal oedema due to endothelial decompensation, until vascularisation results in complete scarring and full integration of the tectonic graft into the eye wall (Fig. 5c).

\section{Pseudoexfoliation Syndrome Following Penetrating Keratoplasty in Young Patients with Keratoconus}

Pseudoexfoliation syndrome following penetrating keratoplasty in young patients with keratoconus has been reported in 3 eyes of 2 patients. ${ }^{179}$ The patients' ages at keratoplasty were 37,40 and 31 years and pseudoexfoliation was first observed 5, 4 and 6 years following keratoplasty, respectively. The respective donor age was in the eighth decade. Possible explanations include mere coincidence, some sort of non-specific reaction to surgery or to postoperative medications, or an immunogenic reaction to transplanted corneal tissue. Finally, the very hypothetical speculation cannot be ruled out that we might be dealing with a completely unknown induction process or even an obscure infection.

As the need for corneal transplantation increases, more attention needs to be paid to the effect of the corneal graft on the host tissue. We may learn that these are not just esoteric observations but of clinical significance.

\section{NEW APPROACHES TO OLD PROBLEMS IN CORNEAL TRANSPLANTATION}

The results of corneal transplantation in the standard situations are better than in any other type of transplantation in humans. However, as the total number of corneal transplantations is large, problems of even relatively low frequency affect many patients. I shall touch here only on selected aspects in the following five problem areas:

\section{Shortage of Donor Material}

A worldwide shortage of suitable donor tissue is the main obstacle to treating corneal blindness. ${ }^{180}$

\section{Autologous Donor Tissue}

One alternative option in case of shortage of donor tissue is the use of autologous tissue via ipsilateral rotation of the opaque central parts of the cornea to the periphery (Fig. 17). Another option is the use of patients' contralateral cornea from an amaurotic eye, due to optic nerve or retinal disease. ${ }^{181,182}$

\section{Phototherapeutic Keratectomy (PTK)}

Superficial corneal processes removed by $193 \mathrm{~nm}$ excimer laser may be an alternative to conventional lamellar or penetrating keratoplasty. ${ }^{183}$ Currently this is our preferred method in superficial nonvascularised scars of the cornea and in superficial corneal dystrophies such as granular or ReisBückler's corneal dystrophy. ${ }^{183-185}$

\section{Keratoprosthesis}

Methyl acrylate and other plastic material usually proves to be an unsatisfactory keratoprosthesis in the long run, particularly as a result of late epithelial ingrowth and irreversible secondary glaucomas. ${ }^{186,187}$

\section{Experimental Seeding of Corneal Endothelial Cells}

Injection of suspensions of corneal endothelial cells is not yet a realistic approach to replace the loss of corneal endothelial cells in Fuchs' dystrophy and secondary corneal endothelial decompensation. It is still not applicable to the clinical situation because, for example, the spread of endothelial cells cannot be

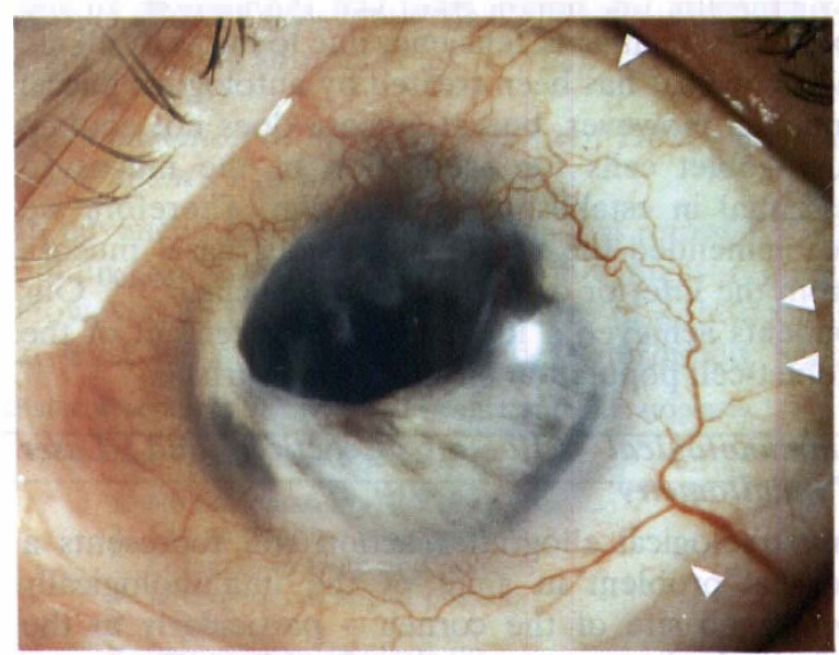

Fig. 17. Oversize $15 \mathrm{~mm}$ corneoscleral graft in deep lamellar scleral bed, for acute severe melting of the anterior segment due to lye-burn in a 50-year-old woman (oculus ultimus). Following systemic therapy with cyclosporin $A$ for 20 months, extracapsular cataract extraction and continuous local corticosteroid therapy the cornea remains clear after 7 years. Laser tyndallometry facilitates monitoring and titration of minimal doses of effective immunosuppressive therapy. 


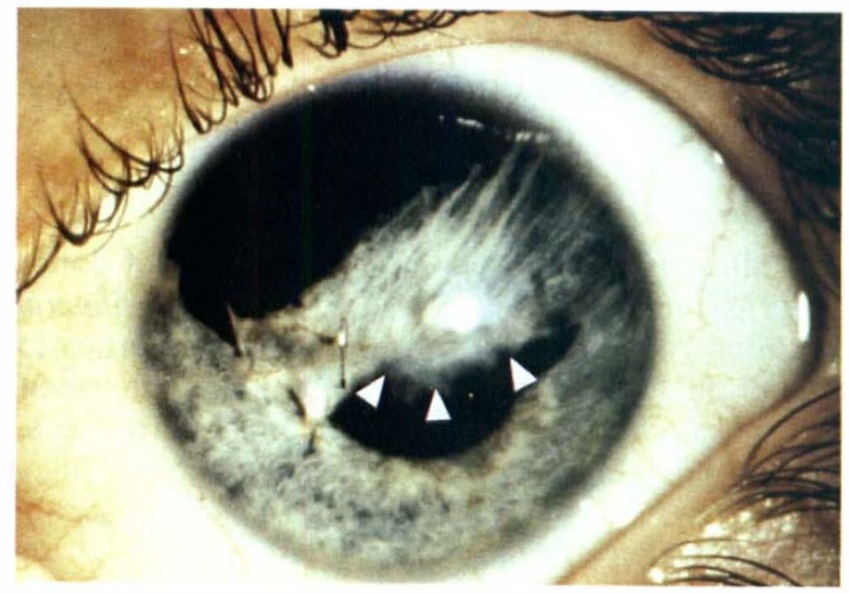

(a)

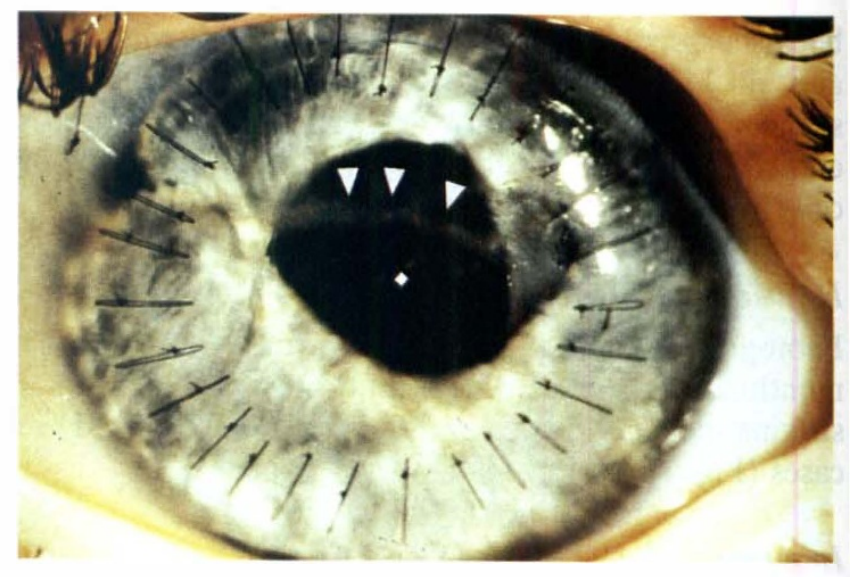

(b)

Fig. 18. Ipsilateral autologous rotational keratoplasty after perforating corneal injury with traumatic iridodialysis and cataract in a 10-year-old boy. (a) Central corneal scar (arrowheads). (b) Six months after eccentric 7 mm perforating keratoplasty. The scar is rotated from the centre of the cornea (diamond) superiorly (arrowheads). Iridopexy and extracapsular cataract aspiration with posterior chamber lens implantation: visual acuity score 0.820 months later.

confined to the back of the cornea within Schwalbe's line. ${ }^{188}$ Finally, the idea of seeding a collagen gel with the recipient's fibroblasts is currently only a hypothetical approach. In the best of circumstances, this could lead to a synthetic 'tectonic biograft'. Even more futuristic is the idea of covering one surface with viable endothelial cells with the goal of producing transparent features for synthetic grafts.

\section{Surface Problems}

Various chronic surface processes leading to unilateral mucus deficiency syndrome may be amenable to autologous limbal grafts with the goal of reestablishing the limbal stem cell population. In the past bilateral mucus deficiency due to burns by alkali, acids or heat has been treated by autologous buccal mucosa. However, buccal mucosa does not contain any goblet cells for production of the mucus so essential in establishing a tear film. Therefore we recommended the use of autologous nasal mucosa from the inferior or middle nasal concha. ${ }^{189,190}$ Our patients achieved a long-lasting replacement of the goblet-cell population on the ocular surface.

\section{Immunological Allograft Reaction and Laser Tyndallometry}

Immunological allograft reaction still represents a serious problem in spite of the immunologically privileged site of the cornea - particularly in the vascularised cornea associated with surface problems. ${ }^{191-208}$ Küchle et al. ${ }^{209}$ have shown that quantifying defects in the blood-aqueous barrier by laser tyndallometry can be of help for the follow-up of patients after corneal transplantation. This allows the early diagnosis of an immune reaction and the monitoring and titrating of local and systemic therapy. Measurement of the aqueous flare appears particularly useful in the following situations: (1) early diagnosis of the beginning of a corneal graft reaction; (2) follow-up of high-risk patients (Fig. 18); (3) monitoring therapeutic effect and titrating the maintenance dosages of corticosteroids or immunosuppressive agents in eyes with manifest or past corneal graft reactions. Of course, the best way to avoid the problem of immunological allograft reaction is to use the patient's own cornea, as in ipsilateral rotational grafts or contralateral autografts (Fig. 16).

\section{Recurrences \\ Corneal Stromal Dystrophies}

Recurrences of the original corneal disease on the graft can be a problem in Reis' granular and Bücklers' lattice dystrophy. Superficial photokeratectomy may be an alternative to regrafting. $183,184,185$

\section{'Reinfection' of the Graft}

As mentioned above, we think that in infectious processes non-mechanical trephination with the excimer laser may offer the advantage that wound margins are 'disinfected' and the danger of smearing of infectious agent to as yet uninfected parts of the patient cornea is reduced. The recurrence of viral diseases in corneal transplantation following herpes corneae may still be problematic. ${ }^{210-213}$ Viral antigen can be demonstrated in excised corneal specimens, especially if the patient's cornea is not vascularised. This may indicate a higher risk for reinfection. Excised corneal tissue after regrafting for herpes corneae showed viable virus elements in $50 \%$, although the non-vascularised grafts were clinically 
Table V. Graft decentration ( \pm SD) after non-mechanical trephination with the $193 \mathrm{~nm}$ excimer laser in penetrating keratoplasty compared with that after conventional motordriven trephination $(n=50)$

\begin{tabular}{lcc}
\hline & $\begin{array}{c}\text { Excimer } \\
\text { laser }\end{array}$ & $\begin{array}{c}\text { Motor } \\
\text { trephine }\end{array}$ \\
\hline Relative to the pupil $(\mathrm{mm})$ & $0.33 \pm 0.26$ & $0.64 \pm 0.24$ \\
Relative to the limbus $(\mathrm{mm})$ & $0.23 \pm 0.25$ & $0.58 \pm 0.27$ \\
\hline After Langenbucher ${\text { et } \text { al. }^{224}}$ & &
\end{tabular}

interpreted as suffering from immune reaction. ${ }^{212}$ Vascularised scars after herpes corneae are more vulnerable to an immune reaction. Immunohistological evaluation of the excised corneal tissue in herpes corneae can be helpful in the post-keratoplasty follow-up. .11-213 $^{-13}$

\section{Astigmatism after Penetrating Keratoplasty}

Even in 1859 , Sir William Bowman was trying to improve the life of patients with keratoconus by transforming the pupil into a vertical slit by 'iridesis' with apparent stenopedic effects. He also thought that this would reduce the curvature of the eye in patients with keratoconus. ${ }^{73}$

Astigmatism after an otherwise successful corneal transplantation resulting in a clear graft is still an unsolved and serious problem, particularly in keratoconus, and more than an annoyance to the patient. $^{214-223}$ Short-term post-operative astigmatism is obviously determined by the sutures. Bigar $^{79}$ reported persisting post-keratoplasty astigmatism of over 8 dioptres in $10 \%$ of keratoconus patients, Kirkness et al. ${ }^{196}$ reported $18 \%$ 'intolerable' astigmatism. Persisting long-term astigmatism after removal of the suture, however, seems to be influenced by the following factors:

\section{Decentration of the Graft}

Tissue excised eccentrically from the donor eye and decentration of the patient's corneal trephine opening can lead to marked discrepancies of the opposing wound edges and distortion to the corneal surface topography. The centration can be related to the corneal apex, the pupil, optical axis and to the limbus. Only some of the motor-driven mechanical trephines satisfactorily allow centration during trephination. The most problematic indication is keratoconus, as extreme corneal astigmatism leads to additional prismatic 'shift of the pupil'.

In a group who had excimer laser trephination there was a statistically significant improvement of the centration of the graft in relation to the pupil and also to the limbus compared with the centration of the graft following motor-driven mechanical trephination (Table V).224

\section{'Vertical Tilt'}

As a consequence of mechanical trephination, the angles of cut usually deviate from the perpendicular vertical direction. In addition, the cut angle differs in the donor's and in the patient's cornea. In order to achieve water-tight closure, the sutures must be pulled, causing a marked distortion of the corneal surface topography. This can be improved by nonmechanical trephination under the condition of perfectly horizontal positioning of the patient's cornea and the mask. Horizontal positioning of the limbal plane is easily achieved if the focusing device of the excimer laser is similarly placed at the 3, 6, 9 and 12 o'clock position. Horizontal positioning of the metal mask is achieved by observing total reflection of coaxial light by the surgical microscope.

\section{'Horizontal Torsion'}

Horizontal torsion follows asymmetrical suturing of the donor cornea into the patient's cornea. Ideal symmetrical placement after circular trephination is very difficult to achieve. The apposition of the eight orientation teeth on the donor button with the corresponding orientation notches on the patient's cornea allows easy symmetrical placement of the first eight principal sutures (Figs. 10, 12).

\section{Harmonisation of the Topography of Donor Cornea and Patient's Cornea}

In advanced cases of keratoconus it is impossible to obtain any satisfactory topographic measurement. However, in the intermediate stages of keratoconus at least the steepest axis can be determined. Seitz

Table VI. Advantages and disadvantages of mechanical and non-mechanical trephination methods in penetrating keratoplasty

\begin{tabular}{|c|c|c|}
\hline & Mechanical trephination & Non-mechanical trephination \\
\hline Advantages & $\begin{array}{l}\text { 1. Feasible also in vascularised scars } \\
\text { 2. Less expensive (currently!) }\end{array}$ & $\begin{array}{l}\text { 1. No deformation } \\
\text { 2. Cut angle same in donor/host } \\
\text { 3. Orientation teeth and notches } \\
\text { 4. Divergent cut angles possible } \\
\text { 5. 'Open eye' } \\
\text { 6. 'Disinfection' in ulcers (?) } \\
\text { 7. Better centration } \\
\text { 8. Post-operative astigmatism more regular, less } \\
\text { asymmetrical } \\
\text { 9. Reduced aqueous flare }\end{array}$ \\
\hline Disadvantages & $\begin{array}{l}\text { 1. Deformation of wound edges: 'vertical tilt', } \\
\text { 'horizontal torsion' } \\
\text { 2. Centration more difficult }\end{array}$ & $\begin{array}{l}\text { 1. Currently not feasible in vascularised scars } \\
\text { 2. Stop by aqueous exit }\end{array}$ \\
\hline
\end{tabular}



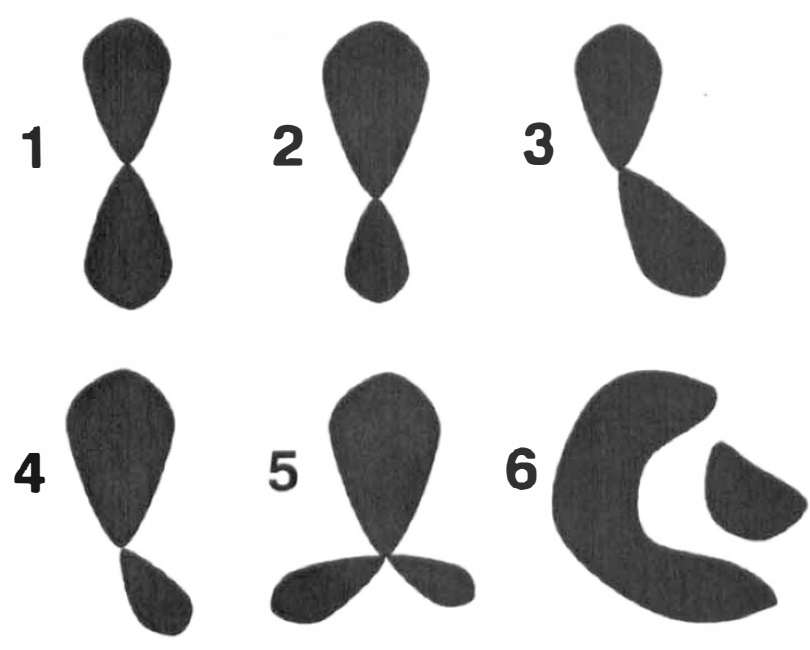

(a)

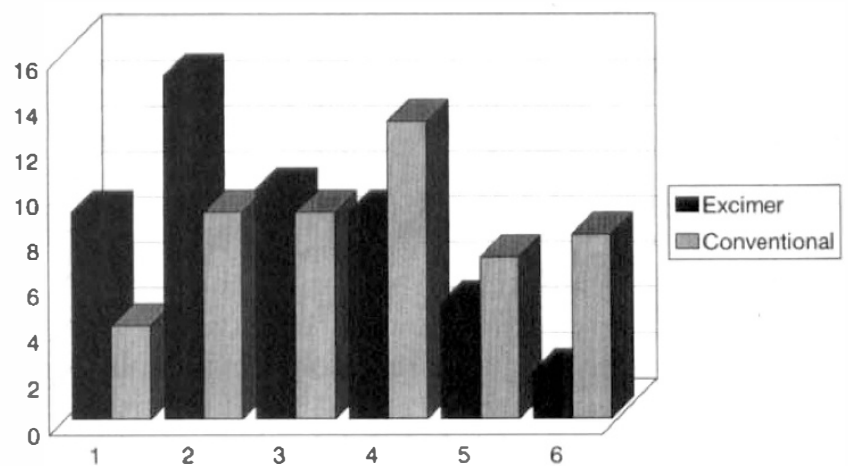

(b)

Fig. 19. Post-keratoplasty astigmatism: 'degree of irregularity' in corneal topography. (a) Definition: six groups according to the location of the steepest axis. (b) Preliminary results of a prospective randomised clinical study comparing two groups of 50 patients following penetrating keratoplasty after either conventional motor-driven trephination or non-mechanical trephination with the $193 \mathrm{~nm}$ excimer laser along a metal mask with eight orientation teeth/notches and with double running sutures in place. There is less irregularity in the excimer group and visual acuity is better (0.61 compared with 0.39).

et al. ${ }^{225,226}$ have developed a method for measuring the topography of the donor tissue after it is fixed in the artificial anterior chamber. Using as orientation the largest orientation tooth, the steepest axis of astigmatism of patient and cornea can be 'harmonised'. This should help to avoid one aspect of the discrepancy between patient's and donor cornea.

\section{Preliminary Results of a Prospective Randomised Clinical Study}

Since 1993, I have treated two groups of 51 patients using mechanical and non-mechanical trephination. Greater numbers and a longer follow-up will be needed to obtain better information. Table VI summarises our observations so far.

Patients. Each group consisted of 32 patients with keratoconus (using graft diameters of $8.1 \mathrm{~mm}$ for a recipient opening of $8.0 \mathrm{~mm}$ ) and 19 patients with Fuchs' dystrophy (using $7.6 \mathrm{~mm}$ graft diameter for a $7.5 \mathrm{~mm}$ recipient opening). All patients treated by excimer laser trephination had the eight orientation teeth and notches on donor button and host cornea respectively; a double running suture was used to secure the graft.

Astigmatism. As long as both sutures were in place there was no significant difference in astigmatism between the mechanical and non-mechanical trephination groups, although there is a positive learning curve for the entire excimer trephination group. There is a trend for reduced astigmatism after removal of sutures in the excimer group (though the numbers of patients are still too small) and increased astigmatism in the conventional group. Finally a statistically significant difference is observed as regards the regularity of the astigmatism in favour of non-mechanical trephination: this may explain the fact that the best corrected visual acuity is 0.6 in the excimer group and 0.4 in the conventional group (Fig. 19).

I will conclude with the words of Sir William Bowman from his Address on Surgery 1866: 'I have endeavoured to give you - I fear at too great length my general impression on this head - I hope without offence to anyone and with sincerity and very inadequately'.227

\section{SUMMA RY}

The following aspects have briefly been touched upon in this Bowman Lecture:

\section{Indications}

Ninety years after its introduction penetrating keratoplasty is today the oldest and most frequently performed and most successful transplantation in humans. It is indicated not only for the obvious optical reasons, but also for a wide spectrum of tectonic indications.

Tectonic full-thickness corneal scleral grafts in an eccentric position are essential for closing iatrogenic defects in the eye wall following block excision for tumours of the anterior uvea, cystic and diffuse epithelial ingrowth and congenital cysts of iris and ciliary body. Corneal transplantation in these indications is a prerequisite for the preservation of the globe with as much vision as possible. The scleral spur is a critical structure in any peripheral corneal degeneration treated by limbal corneal graft fixed in a deep lamellar scleral bed and should be preserved.

Ipsilateral autologous corneal transplantation may be the best access for lens surgery in patients with extreme microcornea. 
Corneal transplantation is contraindicated in all patients with sclerocornea and many with Peters' anomaly associated with microcornea; optical sector iridectomy appears to be a better option in the latter.

New indications for corneal transplantation may be 'PEX keratopathy' (corneal endothelial involvement and decompensation in pseudoexfoliation syndrome) and corneal scarring as part of Münchhausen syndrome.

\section{Surgical Technique}

Bowman's lamina is a critical structure to be considered in all corneal surgery and details of suturing.

Non-mechanical trephination with the $193 \mathrm{~nm}$ excimer laser around a metal mask was done in 124 eyes of 124 patients between 1989 and 1994 without any unexpected complications. It offers the following advantages over mechanical trephination. As mechanical deformation of the donor's and patient's cornea is avoided, problems of decentration, 'vertical tilt' and 'horizontal torsion' can be reduced. Eight orientation teeth and notches allow better placement of the principal sutures and running sutures, and are a prerequisite for orienting the donor tissue into the patient's cornea following 'harmonisation' of the corneal topography in donor and host. Centration of the graft is significantly improved. These factors offer the potential to reduce the persisting post-operative astigmatism following corneal grafting after suture removal. The surgical technique is simple and can be performed under direct control through the operating microscope. Six days after non-mechanical trephination the breakdown of the blood-aqueous barrier is less pronounced than after conventional trephination.

Non-mechanical trephination may also offer advantages in situations of 'open eye', if the patient's cornea is non-vascularised. Infectious processes in non-vascularised corneas not responding to medical therapy may benefit from a 'disinfection' of the wound margins by non-mechanical excision with the $193 \mathrm{~nm}$ excimer laser patterned after the location of the infiltrate.

\section{Effects of the Donor Tissue on the Patient's Cornea}

The effects of donor tissue on the patient's cornea deserve more attention and promise a better understanding of the interaction between donor and host. Clearing of the patient's cornea can be striking after penetrating keratoplasty in Maroteaux-Lamy syndrome and in diffuse endothelial decompensation.

\section{Old Problems and New Approaches}

Ipsi- and contralateral autologous keratoplasty avoids an immune reaction. It should be considered more of ten, particularly in children.
Autologous nasal mucosa transplants are suggested to reduce mucus deficiency syndromes in desperate bilateral ocular surface problems preceding keratoplasty. They appear to be superior to conventional buccal mucosa transplants.

Laser tyndallometry allows early diagnosis of corneal graft immune reaction, monitoring and titration of local and systemic therapy with immunosuppressive medications.

Preliminary results from a prospective randomised study of two groups of 51 patients (since 1993) reveal that with non-mechanical trephination there is a trend for less astigmatism and a statistically significant reduction in the irregularity of post-keratoplasty astigmatism. With sutures still in place, the postkeratoplasty astigmatism is significantly less irregular and visual acuity is significantly better than after conventional trephination.

This lecture was presented at the Annual Meeting of the Royal College of Ophthalmologists, Guernsey, 21 April 1994.

The privilege of delivering the Fifty-sixth Bowman Lecture offers me a very welcome opportunity to express my sincere gratitude to my mentors in ophthalmology: Hans Sautter of Hamburg, Germany and L. E. Zimmerman of Washington, USA (L. E. Zimmerman gave the Forty-ninth Bowman Lecture in 1980); also to my former co-workers, who are now Chairmen and Professors of University Departments: H. E, Völcker of Heidelberg, K. W. Ruprecht of Homburg, Saar (who helped with obtaining all the previous Bowman Lectures from his library), G. K. Lang of Ulm (who led our extensive experimental research on non-mechanical trephination preceding its application to patients) and Z. Zagórski of Lublin, Poland. I would also like to thank my co-workers in our 'cornea group': B. Seitz (my principal collaborator in the excimer project since 1991) A. Langenbucher, M. M. Kus, A. Jünemann, A. Händel, M. Küchle, N. Nguyen, C. Rummelt, V. Rummelt, H. Strahwald, M. Weilersbacher, H. Wenkel, J. Wildt, U. Schlötzer-Schrehardt, L. M. Holbach, and finally the entire staff (G. Gusek, J. Jonas, M. Korth, H. Knorr, U. Mayer, U. Schönherr) and all co-workers including the nurses and the administrative and technical staff of the Department of Ophthalmology and Eye Hospital of the University Erlangen-Nürnberg, Erlangen, Germany. Prof. R. Wittern, chairperson of the Department of History of Medicine at Erlangen, helped with the historical literature.

Key words: Block excision, Bowman Lecture 1994, Excimer laser $193 \mathrm{~nm}$, Graft-versus-host effects, Non-mechanical trephination, Pseudoexfoliation keratopathy, Spectrum of corneal transplantation.

\section{REFERENCES}

\section{Bowman Lecturers}

1. Hutchinson J. Certain diseases of the eye to gout. The Bowman Lecture 1884 (1). Trans Ophthalmol Soc UK $1884 ; \mathrm{V}: 1-30$.

2. Jackson JH. Ophthalmology and diseases of the nervous system. The Bowman Lecture 1885 (2). Trans Ophthalmol Soc UK 1885;VI:1-22.

3. Zehender W. von. Parasitical disease of the eye. The 
Bowman Lecture 1886 (3). Trans Ophthalmol Soc UK 1886;VII:1-18.

4. Power H. Relation of ophthalmic disease to certain normal and pathological conditions of the sexual organs. The Bowman Lecture 1887 (4). Trans Ophthalmol Soc UK 1887; VIII:1-.

5. Swanzy HR. Eye symptoms in the localisation of cerebral disease. The Bowman Lecture 1888 (5). Trans Ophthalmol Soc UK 1888;IX:1-.

6. Grut EH. Pathogeny of concomitant squinting (convergent and divergent). The Bowman Lecture 1889 (6). Trans Ophthalmol Soc UK 1889;X:1-.

7. Hulke JW. Sir William Bowman's work in relation to ophthalmology. The Bowman Lecture 1890 (7). Trans Ophthalmol Soc UK 1890;XI:1-.

8. Leber T. Present position of our knowledge of inflammation with special reference to inflammation of the eye. The Bowman Lecture 1892 (8). Trans Ophthalmol Soc UK 1892;XII:1-28.

9. Teale TP. Abandonment of iridectomy in the extraction of hard cataract. The Bowman Lecture 1893 (9). Trans Ophthalmol Soc UK 1893; XIII:1-.

10. Gowers WR. Subjective visual sensations. The Bowman Lecture 1895 (10). Trans Ophthalmol Soc UK 1895;XV:1-.

11. Snellen $H$. Notes on vision and retinal perception. The Bowman Lecture 1896 (1). Trans Ophthalmol Soc UK 1896;XVI:1-.

12. Smith P. On the etiology and educative treatment of convergent strabismus. The Bowman Lecture 1898 (12). Trans Ophthalmol Soc UK 1898;XVIII:2-.

13. Gunn M. On visual sensation. The Bowman Lecture 1900 (13). Trans Ophthalmol Soc UK 1900;XX:1-.

14. Fuchs E. On keratitis. The Bowman Lecture 1902 (14). Trans Ophthalmol Soc UK 1902;XXII:15-36.

15. Mott FW Sir. The Bowman Lecture 1904 (15). Not available in published form.

16. Sattler H. The pathology and treatment of myopia. The Bowman Lecture 1907 (16). Trans Ophthalmol Soc UK 1907;XXVII:1-26.

17. Nettleship E. On some hereditary disease of the eye. The Bowman Lecture 1909 (17). Trans Ophthalmol Soc UK 1909;XXIX:1-.

18. Landolt E. On ophthalmic surgery. The Bowman Lecture 1911 (18). Trans Ophthalmol Soc UK 1911;XXXI:?-.

19. Uthoff W. Ophthalmic experiences and considerations on the surgery of cerebral tumours and tower skull. The Bowman Lecture 1914 (19). Trans Ophthalmol Soc UK 1914;XXXIV:47-123.

20. Berry GA Sir. Colour-sense phenomena and some inferences which they seem to suggest. The Bowman Lecture 1917 (20). Trans Ophthalmol Soc UK 1917;XXXVII:5-.

21. Morax V. Plastic operations on the orbital region, including restoration of the eyebrows, eyelids and orbital cavity. The Bowman Lecture 1919 (21). Trans Ophthalmol Soc UK 1919;XXXIX:5-.

22. Collins ET. Changes in the visual organs correlated with the adoption of arboreal life and with the assumption of the erect posture. The Bowman Lecture 1921 (22). Trans Ophthalmol Soc UK $1921 ;$ XLI:10-

23. Schweinitz GE de. Concerning certain ocular aspects of pituitary body disorders, mainly exclusive of the usual central and peripheral hemianopic defects. The Bowman Lecture 1923 (23). Trans Ophthalmol Soc UK 1923;XLIII:12-

24. Parsons JH. The foundations of vision. The Bowman
Lecture 1925 (24). Trans Ophthalmol Soc UK 1925;XLV:14 -.

25. Paesons J Sir. The Bowman Lecture 1926 (25). Not available in published form.

26. Smith GE. The new vision. The Bowman Lecture 1928 (26). Trans Ophthalmol Soc UK 1928;XLVIII:44-.

27. Keith A Sir. The genius of William Bowman. The Bowman Lecture 1930 (27). Trans Ophthalmol Soc UK 1930;XL:32-

28. Hoeve $\mathrm{J}$ van der. Ocular movements. The Bowman Lecture 1932 (28). Trans Ophthalmol Soc UK 1932;LII:1-.

29. Usher $\mathrm{CH}$. On a few hereditary eye affections. The Bowman Lecture 1935 (29). Trans Ophthalmol Soc UK 1935;LV:164-.

30. Weve $\mathrm{H}$. On diathermy in ophthalmic practice. The Bowman Lecture 1939 (30). Trans Ophthalmol Soc UK 1939; LIX:43-.

31. Knapp A. The present state of the intracapsular cataract operation. The Bowman Lecture 1946 (31). Trans Ophthalmol Soc UK 1946;LXVII:133-.

32. Amsler M. New clinical aspects of the vegetative eye. The Bowman Lecture 1948 (32). Trans Ophthalmol Soc UK 1948;LXIX:45-76.

33. Dale H Sir. The eye as a physiological reagent. The Bowman Lecture 1951 (33). Trans Ophthalmol Soc UK 1951;LXXII:117-

34. Jefferson G Sir. Concerning injuries, aneurysms and tumours involving the cavernous sinus. The Bowman Lecture 1953 (34). Trans Ophthalmol Soc UK 1953;LXXIII:117-.

35. Dunnington JH. Ocular wound healing with particular reference to the cataract incision. The Bowman Lecture 1955 (35). Trans Ophthalmol Soc UK 1955; LXXV:137-.

36. Duke-Elder Sir S. The aetiology of simple glaucoma. The Bowman Lecture 1957 (36). Trans Ophthalmol Soc UK 1957;LXXVII:205-.

37. Paufique L. The present status of the treatment of the retinal detachment. The Bowman Lecture 1959 (37). Trans Ophthalmol Soc UK 1959;LXXIX:221-48.

38. Mann I. Climate, culture and eye disease. The Bowman Lecture 1961 (38). Trans Ophthalmol Soc UK 1961;LXXXI:261-

39. Brain L. The diagnosis, prognosis and treatment of endocrine exophthalmos. The Bowman Lecture 1962 (39). Trans Ophthalmol Soc UK 1962;LXXXII:223-.

40. Cohen of Birkenhead Lord. Where medicine and ophthalmology meet: some personal experiences. The Bowman Lecture 1964 (40). Trans Ophthalmol Soc UK 1964;LXXXIV:183-.

41. Ashton N. Blood-retinal barrier and vaso-glial relationships in retinal disease. The Bowman Lecture 1965 (41). Trans Ophthalmol Soc UK 1965;85:199_ 230.

42. Hogan MJ. Bruch's membrane and disease of the macula: role of elastic tissue and collagen. The Bowman Lecture 1967 (42). Trans Ophthalmol Soc UK 1967;87:109-61.

43. Pickering G Sir. The eye as an index of generalized vascular disease. The Bowman Lecture 1969 (43). Trans Ophthalmol Soc UK 1969;89:83-.

44. Reese AB. Expanding lesions of the orbit. The Bowman Lecture 1971 (44). Trans Ophthalmol Soc UK 1971;91:85-.

45. Goldmann H. On the slitlamp. The Bowman Lecture 1973 (45). Trans Ophthalmol Soc UK 1973;93:51-.

46. Jones BR. The prevention of blindness from 
trachoma. The Bowman Lecture 1975 (46). Trans Ophthalmol Soc UK 1975;95:16-.

47. Whitteridge D. The cortical contribution to binocular vision. The Bowman Lecture 1977 (47). Trans Ophthalmol Soc UK 1977;97:39-.

48. Davson H. The little brain. The Bowman Lecture 1979 (48). Trans Ophthalmol Soc UK 1979;99:21-.

49. Zimmerman LE. Metastatic disease from uveal melanomas. The Bowman Lecture 1980 (49). Trans Ophthalmol Soc UK 1980;100:34-54.

50. Young RW. Biological renewal: applications to the eye. The Bowman Lecture 1982 (50). Trans Ophthalmol Soc UK 1982;102:42-75.

51. Kupfer C. The conquest of cataract: a global challenge. The Bowman Lecture 1984 (51). Trans Ophthalmol Soc UK 1985;104:1-10.

52. Foulds WS. 'Blood is thicker than water'. Some haemorheological aspects of ocular disease. The Bowman Lecture 1986 (52). Eye 1987;1:343-63.

53. Noorden $G$ von. Current concepts of infantile esotropia. The Bowman Lecture 1988 (53). Eye 1988;2:343-57.

54. Pearce JL. The advantages of extracapsular versus intracapsular extraction: more apparent than real? The Bowman Lecture 1990 (54). Unpublished.

55. Drance SM. Glaucoma: changing concepts. The Bowman Lecture 1992 (55). Eye 1992;6:337-45.

\section{Historical Notes}

56. Burdon-Sandeson J, Hulke JW, editors. The collected papers of Sir William Bowman, Bart., FRS. Edited for the Committee of the Bowman Testimonial Fund. London: Harrison and Sons, St Martin's Lane, 1892.

57. Bowman W. Lectures on the anatomy of the parts concerned in the operation on the eye 1874. In: Burdon-Sandeson J, Hulke JW, editors. The collected papers of Sir William Bowman, Bart., FRS. Edited for the Committee of the Bowman Testimonial Fund. London: Harrison and Sons, St Martin's Lane, 1892.

58. von Graefe A. Letter to his Fried Waldau. In: von Graefe Heynold B. Albrecht von Graefe: Mensch und Umwelt. Munich: Thieme, 1969:40,59.

59. von Graefe Heynold B. Albrecht von Graefe: Mensch und Umwelt. Munich, Thième, 1969.

60. von Graefe A. Letter to Hermann Helmholtz (Berlin, 7.11.1851). In: von Graefe Heynold B. Albrecht von Graefe: Mensch und Umwelt. Munich: Thième, 1969:59.

61. Bowman W. Iridectomy in glaucoma. In: BurdonSandeson J, Hulke JW, editors. The collected papers of Sir William Bowman, Bart., FRS. Edited for the Committee of the Bowman Testimonial Fund. London: Harrison and Sons, St Martin's Lane, 1892:283.

62. Bowman W. Further remarks on glaucoma and the results of iridectomy. By Prof A. von Graefe, with notes by $\mathrm{Mr}$ W. Bowman. In: Burdon-Sandeson J, Hulke JW, editors. The collected papers of Sir William Bowman, Bart., FRS. Edited for the Committee of the Bowman Testimonial Fund. London: Harrison and Sons, St Martin's Lane, 1892:305.

63. Bowman W. On glaucomatous affections and their treatment by iridectomy (30th Annual Meeting of the British Medical Association in London, 5-8 August 1862). BMJ 1862;[October]:377.

64. Esser A. Geschichte der Deutschen Ophthalmolo- gischen Gesellschaft. Munich: Bergmann, 1957; 2,13,52,19.

65. Münchow W. Geschichte der Augenheilkunde. Stuttgart: Enke, 1984.

66. Lilieu OM. Sir William Bowman (1816-1892). Invest Urol 1972;10:107-8.

67. Bowman W. Inaugural Address by the President to the International Medical Congress, London, 1881. In: Burdon-Sandeson J, Hulke JW, editors. The collected papers of Sir William Bowman, Bart., FRS. Edited for the Committee of the Bowman Testimonial Fund. London: Harrison and Sons, St Martin's Lane, 1892:401.

68. Bowman W. Inaugural Address at the First Meeting of the Ophthalmological Society UK, London, 1881. In: Burdon-Sandeson J, Hulke JW, editors. The collected papers of Sir William Bowman, Bart., FRS. Edited for the Committee of the Bowman Testimonial Fund. London: Harrison and Sons, St Martin's Lane, 1892:409.

69. Bowman W. President's Address at First Annual Meeting of the Ophthalmological Society, 6 June 1881. In: Burdon-Sandeson J, Hulke JW, editors. The collected papers of Sir William Bowman, Bart., FRS. Edited for the Committee of the Bowman Testimonial Fund. London: Harrison and Sons, St Martin's Lane, 1892:413.

70. Mackenzie S, Watson S. Resolution of the Council to establish 'The Bowman Lecture'. Trans Ophthalmol Soc UK 1883:XXIX.

71. Thomson AMW. The life and times of Dr William Mackenzie. Glasgow: Glasgow University Press, 1973.

72. Lichter P. Honoring the history of the Edward Jackson Memorial Lecture. Am J Ophthalmol 1994;117:699-705.

73. Bowman W. On conical cornea and its treatment by operation. In: Burdon-Sandeson J, Hulke JW, editors. The collected papers of Sir William Bowman, Bart., FRS. Edited for the Committee of the Bowman Testimonial Fund. London: Harrison and Sons, St Martin's Lane, 1892:271.

\section{Corneal Transplantation in Anterior Segment Diseases}

74. Zirm E. Eine erfolgreiche totale Keratoplastik. Albrecht von Graefes Arch Klin Exp Ophthalmol 1906;64:580-93.

75. Harms H, Mackensen G. Augenoperationen unter dem Mikroskop. Stuttgart: Thième, 1966.

76. Alberth B. Keratoplastik. Bücherei des Augenarztes 37. Stuttgart: Enke, 1961:1.

77. Barraquer J, Rutlan J. Mikrochirurgie der Kornea. Stuttgart: Enke, 1971:2.

78. Barraquer JJ. Queratomileusis y queratofaquia Bogota, Colombia: Instituto Barraquer, 1980.

79. Bigar F, Herbort CP. Corneal transplantation. Curr Opin Ophthalmol 1992;3:473-81.

80. Castroviejo R. Keratoplastik. Stuttgart: Thieme, 1968:400-2.

81. Cavanagh HD, editor. The cornea. New York: Raven Press, 1988.

82. Elschnig A. Über Keratoplastik. Prag Med Wochenschr 1914;39:3.

83. Filatov VP. Transplantation of the cornea from preserved cadavers' eyes. Lancet 1935;232:1395.

84. Günther G. Spätergebnisse der Keratoplastik. Ber Dtsch Ophthalmol Ges 1991;64:159-64.

85. Hinzpeter EN, Naumann GOH. Transplantation of 
the cornea in man and animal. In: Mashoff JW, editor. Handbuch der Allgemeinen Pathologie, vol. VI/8, Transplantationen. Berlin: Springer, 1977:403-38.

86. Abbott RL, Fine BS, Webster RG, Paglen PG, Spencer WH. Specular microscopic and histologic observations in nonguttate corneal endothelial degeneration. Ophthalmology 1981;88:788-800.

87. Waring GO, Bourne WM, Edelhauser HF, Kenyon KR. The corneal endothelium: normal and pathologic structure and function. Ophthalmology 1982;89:53190.

88. Kaufman HE, et al., editors. The cornea. London: Churchill Livingstone, 1988.

89. Krwawicz T. Lamellar corneal stromectomy. Am J Ophthalmol 1964;57:828-33.

90. Lang GK, Naumann GOH. The frequency of corneal dystrophies requiring keratoplasty in Europe and the USA. Cornea 1987;6:209-11.

91. Lang GK, Wilk CM, Naumann GOH. Wandlungen in der Indikationsstellung zur Keratoplastik (Erlangen, 1964-1986). Fortschr Ophthalmol 1988;85:255-8.

92. Müller HK, Söllner F, Vucicevic Z. Spätergebnisse bei der Keratoplastik. Ber Dtsch Ophthalmol Ges 1961;64:142.

93. Naumann GOH, Sautter H, Bigar F. Surgical procedures on the cornea. In: Blodi FC, Mackensen G, Neubauer H, editors. Surgical ophthalmology 1. Berlin: Springer, 1991:433-508.

94. Neubauer H. Penetrierende Keratoplastik und gedeckte Trepanation in einer Sitzung - bei zerstörtem Kammerwinkel. Klin Monatsbl Augenheilkd 1981;179:378.

95. Paufique L, Sourdille GP, Offret G. Les greffes de la cornée. Paris: Masson, 1948:258.

96. Pouliquen YJM. Doyne Lecture. Keratoconus. Eye 1987;1:1-14.

97. Vail A, Gore SM, Bradley BA, Easty DL, Rogers CA. Corneal graft survival and visual outcome multicenter study. Ophthalmology 1994;101:120-7.

98. Williams KA, Muehlberg SM, Wing SJ, Coster DJ, editors. The Australian Corneal Graft Registry: 1990 to 1992 Report. Aust NZ J Ophthalmol (Suppl) 1993;5:3-48.

99. Bowman W. Thoughts for the medical student. Introductory address delivered at King's College, London, 1 October 1851. In: Burdon-Sandeson J, Hulke JW, editors. The collected papers of Sir William Bowman, Bart., FRS. Edited for the Committee of the Bowman Testimonial Fund. London: Harrison and Sons, St Martin's Lane, 1892:51

100. Naumann G, Hadlok I. Zur Technik der Cyclectomie. Ber Dtsch Ophthalmol Ges 1972;72:481-4.

101. Naumann G. Blockexcision intraokularer Prozesse. I. Tumoren der vorderen Uvea. Klin Monatsbl Augenheilkd 1975;166:436-48.

102. Naumann GOH, Völcker HE, Gäckle D. The blockexcision of malignant melanomas of the ciliary body and the peripheral choroid. Doc Ophthalmol 1980;50:43-8.

103. Naumann GOH. Direct surgery of the ciliary body. In: Heilmann K, Paton D, editors. Atlas of ophthalmic surgery. Stuttgart: Thième, 1987.

104. Naumann GOH. Direct surgery of the ciliary body. The Dr William Mackenzie Memorial Lecture. Glasgow, Scotland, 30 October 1991.

105. Henke V, Naumann GOH. Zur 'Biozytologie' diffuser maligner Melanome der vorderen Uvea. Klin Monatsbl Augenheilkd 1988;192:289-95.
106. Naumann GOH, Eisert S, Gieler J, Baur KF. Kontrollierte Hypotension durch Natrium-Nitroprussid bei der Allgemeinnarkose für schwierige intraokulare Eingriffe. Klin Monatsbl Augenheilkd 1977;170:922-5.

107. Naumann G, Völcker HE. Blockexcision intraokularer Prozesse. II. Epitheleinwachsung in den vorderen Augenabschnitten. Klin Monatsbl Augenheilkd 1975;166:448-57.

108. Küchle M, Naumann GOH. Mucogenic secondary open-angle glaucoma in diffuse epithelial ingrowth treated by block-excision. Am J Ophthalmol 1991;111:230-4.

109. Naumann GOH, Rummelt V. Block excision of cystic and diffuse epithelial ingrowth of the anterior chamber. Arch Ophthalmol 1992;110:223-7.

110. Naumann GOH, Rummelt V. Congenital nonpigmented epithelial iris cyst removed by block-excision. Graefes Arch Clin Exp Ophthalmol 1990;228:392-7.

111. Rummelt V, Naumann GOH. Block excision of congenital and infantile nonpigmented epithelial iris cysts: report on 8 infants. Ger $\mathbf{J}$ Ophthalmol 1992;1:361-6.

112. Naumann G, Green WR. Spontaneous nonpigmented iris cysts. Arch Ophthalmol 1967;78:496-500.

113. Capó H, Palmer E, Nicholson DH. Congenital cysts of the iris stroma. Am J Ophthalmol 1993;116:228-32.

114. Naumann GOH, Völcker HE. Direkte Zyklopexie zur Behandlung des persistierenden HypotonieSyndroms infolge traumatischer Zyklodialyse. Klin Monatsbl Augenheilkd 1981;179:266-70.

115. Küchle M, Naumann GOH. Direct cyclopexy for traumatic cyclodialysis with persisting hypotony. Ophthalmology 1995;102:322-33.

116. Hallermann W. Zur Behandlung der Terrienschen Marginaldystrophie. Klin Monatsbl Augenheilkd 1978:173:770-4.

117. Völcker HE, Naumann GOH. Exzentrische tektonische Mini-Keratoplastik bei kornealen, korneoskleralen und skleralen Prozessen Klin Monatsbl Augenheilkd 1984;185:158-66.

118. Bialasiewicz AA, Naumann GOH. Tektonische Keratoplastik bei perforierendem Hornhautulkus bei Sjögren-Sydnrom. Klin Monatsbl Augenheilkd 1988;193:554-64.

119. Lindberg JG. Kliniska undersökninger över depigmentering av pupillranden och genomlysbarlietav iris vid fall av aldersstaar samt i normalögon hos gamla personer. Thesis, University of Helsinki, 1917.

120. Vogt A. Ein neues Spaltlampenbild des Pupillengebietes: heller Pupillarsaumfilz mit Häutchenbildung auf der Linsenvorderkapsel. Klin Monatsbl Augenheilkd 1925;75:1-12.

121. Wollensak J, Becker HU, Seiler T. Pseudoexfoliationssyndrome und Glaukome. Ger J Ophthalmol 1992;1:32-4.

122. Tarkkanen AHA. Exfoliation syndrome. Trans Ophthalmol Soc UK 1986;105:233.

123. Naumann GOH and the 'Erlanger Augenblätter Group'. Exfoliation syndrome as a risk factor for vitreous loss in extracapsular cataract surgery. Acta Ophthalmol (Copenh) 1988;66(Suppl)184:129-31.

124. Schlötzer-Schrehardt U, Naumann GOH. A histopathologic study of zonular instability in pseudoexfoliation syndrome. Am J Ophthalmol 1994;118:730-43.

125. Schlötzer-Schrehardt U, Koca MR, Naumann GOH Pseudoexfoliation syndrome: ocular manifestation of a systemic disorder. Arch Ophthalmol 1992;110:1752.

126. Streeten BW, Zong-Yi Li, Wallace RN, Eagle RC, 
Keshgegian AA. Pseudoexfoliative fibrillopathy in visceral organs of a patient with pseudoexfoliation syndrome. Arch Ophthalmol 1992;110:1757-62.

127. Schlötzer-Schrehardt U, Dörfler S, Naumann GOH. Corneal endothelial involvement in pseudoexfoliation syndrome. Arch Ophthalmol 1993;111:666-74.

128. Miyake K, Matsuda M, Inaba M. Corneal endothelial changes in pseudoexfoliation syndrome. Am $\mathbf{J}$ Ophthalmol 1989;108:49-52.

129. Knorr HLJ, Jünemann A, Händel A, Naumann GOH. Morphometrische und qualitative Veränderungen des Hornhautendothels bei Pseudoexfoliationssyndrom. Fortschr Ophthalmol 1991;88:786-9.

130. Schlötzer-Schrehardt U, Dörfler S, Naumann GOH. Corneal endothelial involvement in pseudoexfoliation syndrome. Arch Ophthalmol 1993;111:666-74.

131. Naumann GOH, Schlötzer-Schrehardt U, Asano N. Pseudoexfoliation keratopathy. Arch Ophthalmol 1994;112:297-8.

132. Sautter H, Hinzpeter EN, Naumann G. Über Indikation, Technik und Ergebnisse bei Fuchs'scher Hornhautdystrophie. Klin Monatsbl Augenheilkd 1972;160:129-41.

133. Hogan MJ, Wood I, Fine M. Fuchs' endothelial dystrophy of the cornea. Twenty-ninth Sanford Gifford Memorial Lecture. Am J Ophthalmol 1974;78:363-83.

134. Bourne WM, Johnson DH, Campbell RJ. Fuchs' dystrophy. Arch Ophthalmol 1982;100:1952-5.

135. Wilson SE. Fuchs' dystrophy. Cornea 1988;7:2-18.

136. Adamis AP, Filatov V, Tripathi BJ, Tripathi RC. Fuchs' endothelial dystrophy of the cornea. Surv Ophthalmol 1993;38:149-68.

137. Sautter H, Naumann GOH. Erfahrungen mit gleichzeitiger perforierender Keratoplastik und KataraktExtraktion. Klin Monatsbl Augenheilkd 1973;163: 290-8.

138. Schönherr U, Händel A, Ruprecht KW, Naumann GOH. Simultane perforierende Keratoplastik, Katarakt-Extraktion und Kunstlinsen-Implantation ('Triple Procedure') 1981-1987. Klin Monatsbl Augenheilkd 1988;192:644-9.

139. Tetsumoto K, Schlötzer-Schrehardt U, Küchle M, Dörfler S, Naumann GOH. Precapsular layer of the anterior lens capsule in early pseudoexfoliation syndrome. Graefes Arch Clin Exp Ophthalmol 1992;230:252-7.

140. Helbig H, Schötzer-Schrehardt U, Noske W, Kellner U, Foerster MH, Naumann GOH. Anterior chamber hypoxia and iris vasculopathy in pseudoexfoliation syndrome. Ger J Ophthalmol 1994;3:148-53.

141. Naumann GOH, Gloor BP, Wild J, Joraschky P, Lungershausen E. Corneal transplantation in Münchhausen syndrome: report on 4 patients. (In preparation)

142. Ruprecht KW, Naumann G. Perforierende Keratoplastik und Histopathologie der Cornea plana. Klin Monatsbl Augenheilkd 1974;165:585-94.

143. Seitz B, Naumann GOH. Ipsilateral autologous keratoplasty for cataract extraction in extreme microcornea: report of 3 eyes in 2 patients. Ger $\mathbf{J}$ Ophthalmol 1992;(Suppl)1:278.

144. Parmley VC, Stonecipher KG, Rowsey JJ. Peters' anomaly: review of 26 penetrating keratoplasties in infants. Ophthalmic Surg 1993;24:31-5.

145. Naumann GOH, Jünemann A. Peters' anomaly [letter]. Ophthalmic Surg 1994;25:202.

146. Seiler T, Wollensak J. Myopic photorefractive keratectomy with the excimer laser: one year followup. Ophthalmology 1991;98:1156-63.

147. Eimer HH. Zur Klinik und Histopathologie von Rekeratoplastiken. Dissertation, Hamburg, 1972.

148. Mackensen G, Haug HP, Horn C, Sundmacher R, Witschel H. Nahtlockerung nach Keratoplastik und Korrekturmöglichkeiten. Klin Monatsbl Augenheilkd 1978;173:700-7.

149. Waring GO III, Laibson PR. Keratoplasty in infants and children. Trans Am Acad Ophthalmol Otolaryngol 1977;83:283.

150. Schönherr U, Küchle M, Lang GK, Naumann GOH. Keratoplastik im Kindesalter: Bericht über 71 Keratoplastiken. Klin Monatsbl Augenheilkd 1993; 203:167-73.

151. von Hippel A. Eine neue Methode der Hornhauttransplantation. Albrecht von Graefes Arch Klin Exp Ophthalmol 1888;34:108-30.

152. Draeger J. Neue Schneidetechnik in der Mikrochirurgie. Klin Monatsbl Augenheilkd 1971;159:293-303.

153. Naumann G. Einfacher Keratoplastik-Trepan für das Operationsmikroskop. Klin Monatsbl Augenheilkd 1972;161:708-9.

154. Krumeich J, Binder PS, Knülle A. The theoretical effect of trephine tilt on postkeratoplasty astigmatism. CLAO J 1988;14:213-9.

155. Olson RI. Corneal transplantation techniques. In: Kaufman $\mathrm{HE}$ et al., editors. The cornea. London: Churchill Livingstone, 1988:784.

156. Naumann GOH, Seitz B, Lang GK, Langenbucher A. Kus MM. Excimer-Laser-193 nm-Trepanation bei der perforierenden Keratoplastik: Bericht über die ersten 70 Patienten. Klin Monatsbl Augenhẹilkd 1993;203: 252-61.

157. Lang GK, Schröder E, Koch JW, Yanoff M, Naumann GOH. Excimer laser keratoplasty. I. Basic concepts. Ophthalmic Surg 1989;20:262-7.

158. Lang GK, Schroeder E, Koch JW, Yanoff M, Naumann GOH. Excimer laser keratoplasty. II. Elliptical keratoplasty. Ophthalmic Surg 1989;20: 342-6.

159. Gebhardt E, Lang GK, Tittelbach H, Rau D, Naumann GOH. Untersuchungen zur Chromosomenmutagenität eines $193 \mathrm{~nm}$ Excimer Lasers. Fortschr Ophthalmol 1990;87:229-33.

160. Lang GK, Naumann GOH, Koch JN. A new elliptical excision of corneal transplantation using an excimer laser [letter]. Arch Ophthalmol 1990;108:914-5.

161. Naumann GOH, Lang GK, Seitz B, Langenbucher A, Kus MM. Elliptische perforierende Keratoplastik (PK) nach Excimer Laser 193-nm Trepanation. Klin Monatsbl Augenheilkd 1994;204:65.

162. Naumann GOH, Seitz B. Excimer laser 193-nm trephination with 'orientation teeth' in penetrating keratoplasty. Ophthalmology 1992;99(Suppl):146.

163. Seitz B, Langenbucher A, Kus MM, Naumann GOH. Excimer laser $193 \mathrm{~nm}$ trephination with divergent cut angles in penetrating keratoplasty. Invest Ophthalmol Vis Sci 1993;34(Suppl):1085.

164. Kus MM, Seitz B, Langenbucher A, Naumann GOH. Quantitative evaluation of the cut configuration in histological sections of corneal buttons obtained by penetrating keratoplasty (PKP). Ger J Ophthalmol 1993;2:373.

165. Kus MM, Seitz B, Langenbucher A, Naumann GOH. The effect of intraocular pressure on corneal topography of intact cadaver eyes and corresponding corneoscleral buttons. Invest Ophthalmol Vis Sci 1994;35(Suppl):1879. 
166. Naumann GOH, Lang GK, Seitz B. Curative excimer laser surgery. J Jpn Soc Ophthalmic Surg 1992;5:62.

167. Langenbucher A, Seitz B, Kus MM, Naumann GOH. Computerized laser beam control for the donor trephination in penetrating keratoplasty with the excimer laser 193-nm. Ger J Ophthalmol 1993;2:374.

168. Hoffmann F. Nahttechnik bei perforierender Keratoplastik. Klin Monatsbl Augenheilkd 1976;69:584-90.

169. Naumann GOH, Seitz B, Langenbucher A, Kus MM. Excimer laser 193-nm trephination with 'orientation teeth': first results after 50 penetrating keratoplasties (PKP). Ger J Ophthalmol 1993;2:375.

170. Garner A. Amoebic keratitis. $\mathrm{Br} \mathrm{J}$ Ophthalmol 1993;77:376-70.

171. Hallermann W. Keratoplastik aus akuter Indikation. Klin Monatsbl Augenheilkd 1975;167:345.

172. Naumann G, Zimmerman LE, Green WR. Mycotic keratitis: a histopathologic study of 73 cases. Am J Ophthalmol 1967;64:688-82.

173. Naumann GOH. Corneal transplantation for herpes simplex keratitis [letter]. Am J Ophthalmol 1983;96:557.

174. Starzl TE, et al. Chimerism after liver transplantation for type IV glycogen storage disease and type 1 Gaucher's disease. N Engl J Med 1993;328:745-9.

175. Wang L, Juji T, Tokunaga K, Takahashi K, Kuwata S, Uchida S, et al. Brief report: polymorphic microsatellite markers for the diagnosis of graft-versus-host disease. N Engl J Med 1994;330:398-401.

176. Naumann GOH. Clearing of cornea after perforating keratoplasty in mucopolysaccharidosis type VI Maroteaux-Lamy syndrome [letter]. N Engl J Med 1985;312:995.

177. Naumann GOH, Rummelt V. Aufklaren der transplantatnahen Wirtshornhaut nach perforierender Keratoplastik beim Maroteaux-Lamy-Syndrom (Mukopolysaccharidose Typ VI-A). Klin Monatsbl Augenheilkd 1993;203:351-60.

178. Küchle M, Händel A, Naumann GOH. Keratoplastik wegen pseudophaker Hornhaut-Endothel-EpithelDekompensation: Bericht über 152 Augen. Spektrum Augenheilkd 1994;8:1-6.

179. Küchle M, Naumann GOH. Occurrence of pseudoexfoliation following penetrating keratoplasty for keratoconus. Br J Ophthalmol 1992;76:98-100.

180. Bialasiewicz AA, Naumann GOH, Jahn GJ. Virologische Gesichtspunkte bei der Spenderauswahl für allogene Keratoplastik. Klin Monatsbl Augenheilkd 1988;192:634-6.

181. Naumann GOH, Völcker HE, Gäckle D. Ipsilaterale Rotations-Autokeratoplastik. Klin Monatsbl Augenheilkd 1977;170:488-93.

182. Boruchoff SA, Dohlman CH. Corneal autografts. Am J Ophthalmol 1967;63:1677-81.

183. Kubota T, Seitz B, Tetsumoto K, Naumann GOH. Lamellar excimer laser keratoplasty: reproducible photoablation of corneal tissue - a laboratory study. Doc Ophthalmol 1992;82:193-200.

184. Stark WJ, Chamon W, Kamp MT, Enger CL, Rencs EV, Gottsh JD. Clinical follow-up of 193-nm ArF excimer laser photokeratectomy. Ophthalmology 1992;99:805-12.

185. Seitz B, Kus MM, Langenbucher A, Naumann GOH. Phototherapeutische Keratektomie (PTK) mit dem Excimer Laser $193 \mathrm{~nm}$. Klin Monatsbl Augenheilkd 1994;204:66.

186. Dohlman CH, Schneider HA, Doane MG. Prothokeratoplasty. Am J Ophthalmol 1974;77:649-70.
187. Lund O-E. Grenzen und Möglichkeiten der Keratoprothese. Klin Monatsbl Augenheilkd 1982;180:3-12.

188. Zagórski Z, Gossler B, Rummelt C, Grunwald W, Naumann GOH. Low oxygen prevents epithelial overgrowth of corneas in long-term organ culture. Doc Ophthalmol 1990;73:286-9.

189. Naumann GOH, Lang GK, Rummelt V, Wigand M. Autologous nasal mucosa transplantation in severe bilateral conjunctival mucous deficiency syndromes. Ophthalmology 1990;97:1011-7.

190. Wenkel H, Rummelt V, Naumann GOH. Long-term survival of goblet cells after autologous nasal mucosa transplantation. Invest Ophthalmol Vis Sci 1994; 35(Suppl):1794(2508).

191. Maumenee AE. Clinical aspects of the corneal homograft reaction. Invest Ophthalmol 1962;1:244 52.

192. Khodadoust A, Silverstein AM. The survival and rejection of epithelium in experimental corneal transplants. Invest Ophthalmol 1969;8:169-79.

193. Inomata H, Smelser GK, Polack FM. Fine structure of regenerating endothelium and Descemet's membrane in normal and rejecting corneal grafts. Am J Ophthalmol 1970;70:48-64.

194. Kok-van Alphen CCD, Völker-Dieben HJM. Über Abstossungsreaktion des Korneatransplantats und die ersten Versuche mit gewebetypisiertem und HLAangepasstem Spendermaterial. Klin Monatsbl Augenheilkd 1978;173:208.

195. Böhnke M, Draeger J, Niesmann U. Influence of endothelial cell count of donor's cornea on endothelial cell loss. Graefes Arch Clin Exp Ophthalmol 1983;221:41-5.

196. Kirkness CM, Ficker LA, Steele ADM, Rice NSC. The success of penetrating keratoplasty for keratoconus. Eye 1990;4:673-88.

197. Sharif KW, Casey TA. Penetrating keratoplasty for keratoconus: complications and long-term success. $\mathrm{Br}$ J Ophthalmol 1991;75:142-6.

198. Wang L, Juji T, Tokunaga K, Takahashi K, Kuwata S, Uchida S, et al. Brief report: polymorphic microsatellite markers for the diagnosis of graft-versus-host disease. N Engl J Med 1994; 330:398-401.

199. McDonnell PJ, Enger C, Stark WJ, Stulting RD. Corneal thickness changes after high-risk penetrating keratoplasty. Arch Ophthalmol 1993;111:1374-81.

200. Philipp W, Göttinger W. T6-positive Langerhans cells in diseased corneas. Invest Ophthalmol Vis Sci 1991;32:2492-7.

201. Polack FM. Scanning electron microscopy of corneal graft rejection: epithelial rejection, endothelial rejection and formation of posterior graft membranes. Invest Ophthalmol Vis Sci 1972;11:1-14.

202. Price FW, Whitson WE, Collins KS, Marks RG. Fiveyear corneal graft survival: a large, single-center patient cohort. Arch Ophthalmol 1993;111:799-805.

203. The Collaborative Corneal Transplantation Studies (CCTS). Stark W, editor. Effectiveness of histocompatibility matching in high-risk corneal transplantation. Arch Ophthalmol 1992;110:1392-403.

204. Thiel HJ, Manthey KF. Die Häufigkeit von Immunreaktionen nach perforierenden Keratoplastiken. Klin Monatsbl Augenheilkd 1980;177:274-83.

205. Völcker HE, Naumann GOH. Hyperakute HornhautTransplantat-Infiltration mit Uveitis anterior. Ber Dtsch Ophthalmol Ges 1981;78:91.

206. Völker-Dieben HJ, D’Amaro J. Corneal transplantation: a single center experience 1976 to 1988. In 
Terasaki P, editor. Clinical transplantation. Los Angeles: UCLA Tissue Typing Laboratory, 1988.

207. Zierhut M, Pleyer U. Thiel H-J, editors. Immunology of corneal transplantation. Buren, The Netherlands: Aeolus Press, 1994.

208. Zirm M, Göttinger W, Reissigl H. Transplantation gewebetypisierter Hornhäute. Klin Monatsbl Augenheilkd 1982;181:73-8.

209. Küchle M, Nguyen NX, Naumann GOH. Aqueous flare following penetrating keratoplasty and in corneal graft rejection. Arch Ophthalmol 1994;112:354-8.

210. Epstein RJ, Seedor JA, Dreizen NG, Stulting RD, Waring GO III, Wilson LA, Cavanagh HD. Penetrating keratoplasty for herpes simplex keratitis and keratoconus. Ophthalmology 1987;94:935-44.

211. Holbach LM, Bayer J, Seitz B, Rummelt C, Naumann GOH. Herpes-simplex keratitis. Ophthalmologe 1993;90:698-702.

212. Holbach LM, Font RL, Naumann GOH. Herpes simplex stromal and endothelial keratitis granulomatous cell reactions at the level of Descemet's membrane, the stroma and Bowman's layer. Ophthalmology 1990;7:722-8.

213. Wenkel H, Rummelt C, Rummelt V, Jahn G, Fleckenstein B, Naumann GOH. Detection of varicella zoster virus DNA and viral antigen in human cornea after herpes zoster ophthalmicus. Cornea 1993;12:131-7.

214. Troutman RC, Buzard KA. Corneal astigmatism. St Louis: Mosby/Yearbook, 1992.

215. Clinch TE, Thompson HW, Gardner BP, Kaufman SC, Kaufman HE. An adjustable double running suture technique for keratoplasty. Am J Ophthalmol 1993;116:201-6.

216. Eggers C. Der Keratotorus. Klin Monatsbl Augenheilkd 1978;17:551.

217. Filatov V, Steinert RF, Talamo JH. Postkeratoplasty astigmatism with single running suture or interrupted sutures. Am J Ophthalmol 1993;115:715-21.
218. Lindstrom RL. The surgical correction of astigmatism: a clinician's perspective. Lans Distinguished Refractive Surgery Lecture. Refract Corneal Surg 1990;6:441-54.

219. Mader TH, Yuan R, Lynn MJ, Stulting RD, Wilson LA, Waring GO. Changes in keratometric astigmatism after suture removal more than one year after penetrating keratoplasty. Ophthalmology 1993;100: 119-27.

220. Meyer HJ. Postoperative Astigmatismus nach Keratoplastik. Ophthalmologe 1993;90:723-5.

221. Seitz B, Naumann GOH. Limbus-parallel keratotomies and compression sutures in excessive astigmatism after penetrating keratoplasty. Ger J Ophthalmol 1993;2:42-50.

222. Van Meter WS, et al. Postkeratoplasty astigmatism control. Ophthalmology 1991;98:177-83.

223. Witmer R. Der Astigmatismus nach perforierender Keratoplastik beim Keratokonus. Klin Monatsbl Augenheilkd 1981;179:262-3.

224. Langenbucher A, Seitz B, Kus MM, Naumann GOH. Graft decentration in penetrating keratoplasty: excimer laser trephination versus motor trephine. Invest Ophthalmol Vis Sci 1994;35(Suppl):1879.

225. Seitz B, Langenbucher A, Kus MM, Naumann GOH. Consideration of donor and recipient corneal topography improves graft alignment in penetrating keratoplasty. Invest Ophthalmol Vis Sci 1994;35 (Suppl):1879.

226. Seitz B, Langenbucher A, Kus MM, Naumann GOH. Harmonizing of donor and recipient corneal topography in penetrating keratoplasty: first clinical application. Ger J Ophthalmol 1994;3(Suppl):310.

227. Bowman W. The Address in Surgery delivered at the Meeting of the British Medical Association, Chester, 9 August 1866. In: Burdon-Sandeson J, Hulke JW, editors. The collected papers of Sir William Bowman, Bart., FRS. Edited for the Committee of the Bowman Testimonial Fund. London: Harrison and Sons, St Martin's Lane, 1892:69. 